$4 y^{2} \frac{z}{2}$

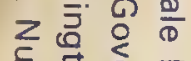

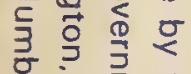

익

$8 \stackrel{0}{\circ}$

$\omega N$ 늠

ㅇํㄱ음

员芯芯

$\vec{u}$
$\omega$
0
1

올

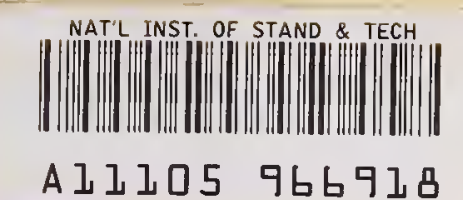

홍

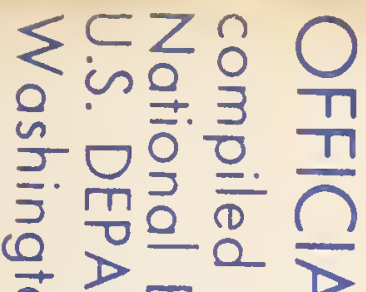

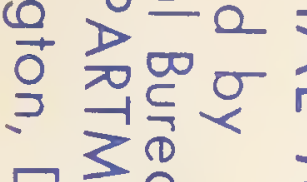

03

ก而足 꿍

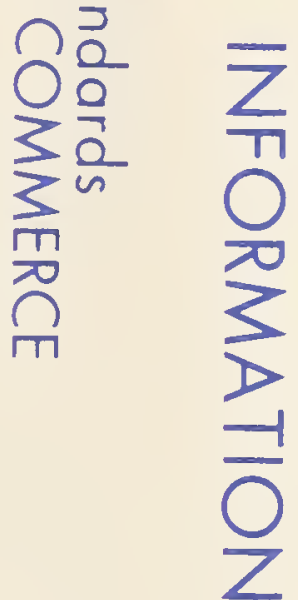
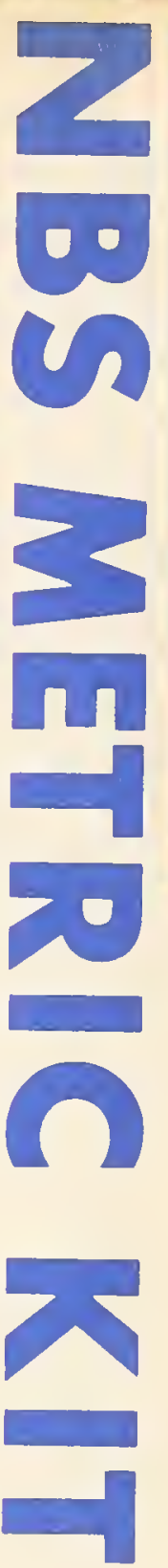



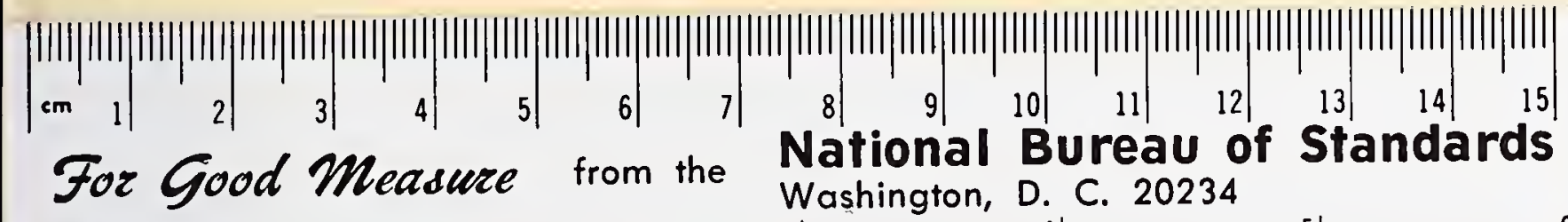

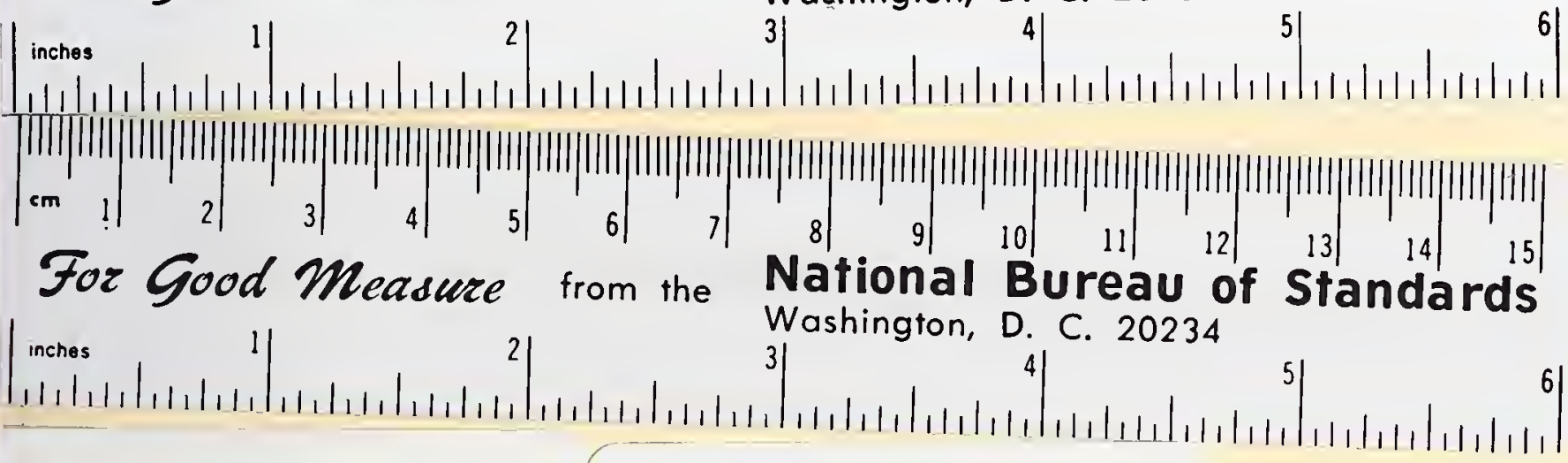
.S. DEPARTMENT OF COMMERCE

ational Bureau of Standards NBS Special Publication 365 C. 20234 Revised May 1976

Approximate Conversions to Metric Measies ymbol

\begin{tabular}{|c|c|c|c|c|}
\hline ymbol & When You Kno & $\begin{array}{c}\text { Multiply by } \\
\text { LENGTH }\end{array}$ & To Find & Symbol \\
\hline $\mathrm{n}$ & inches & 2.5 & centimeters & $\mathrm{cm}$ \\
\hline$t$ & feet & 30 & centimeters & $\mathrm{cm}$ \\
\hline d & yards & 0.9 & meters & $\mathrm{m}$ \\
\hline$\underline{\mathrm{ni}}$ & miles & 1.6 & kilometers & $\mathrm{km}$ \\
\hline \multicolumn{5}{|c|}{ AREA } \\
\hline $\mathrm{n}^{2}$ & square inches & 6.5 & square centimeters & $\mathrm{cm}^{2}$ \\
\hline$t^{2}$ & square feet & 0.09 & square meters & $\mathrm{m}^{2}$ \\
\hline $\mathrm{rd}^{2}$ & square yards & 0.8 & square meters & $\mathrm{m}^{2}$ \\
\hline$i^{2}$ & square miles & 2.6 & square kilometers & $\mathrm{km}^{2}$ \\
\hline & & 0.4 & hectares & \\
\hline
\end{tabular}

square yard

0.4 hectares

ounces $\frac{28 \text { grams }}{28}$

pounds

0.45 kilograms

(2000 lb)

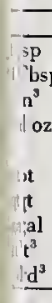

teaspoons

VIUME

$\begin{array}{rrr} & 5 & \text { milliliters } \\ & & \\ & 15 & \text { milliliter }\end{array}$

cubic inches

fuid ounces

pints

quarts

gallons

cet

15 milliliters

30 milliliter

0.24 liters

0.95 liters

$\begin{array}{ll}0.95 & \text { liters } \\ 3.8 & \text { liters }\end{array}$

0.03 cubic

TEM

0.76 culic meters

degrees
Fahrenhe

59 (after degrees

subtracting

Celsius

32)
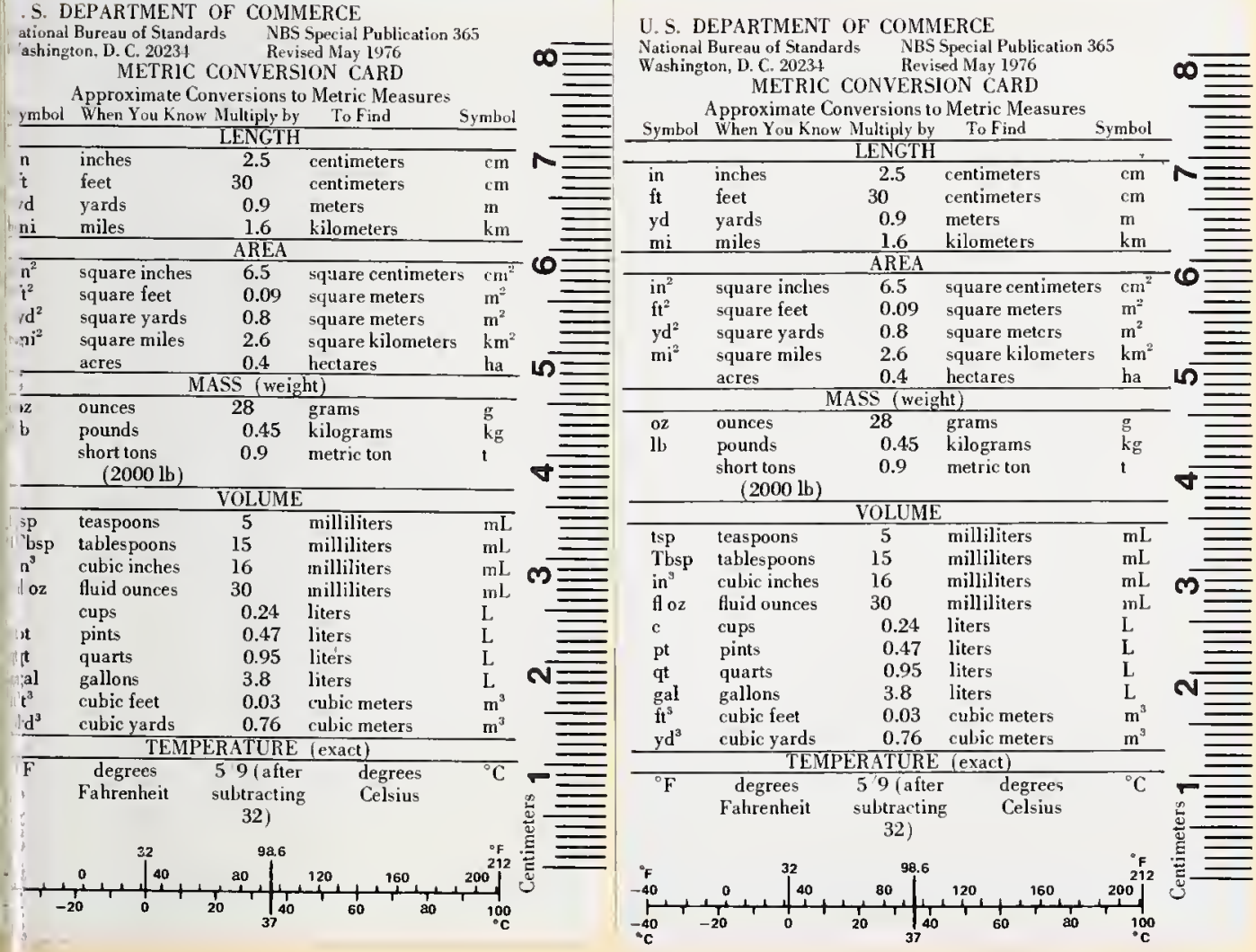


\begin{tabular}{|c|c|c|c|c|}
\hline COMPARE ME & $\begin{array}{l}\text { LIC AND } \\
\text { Length } \\
\text { Meter }\end{array}$ & $\begin{array}{l}\text { CUSTOMARY UR } \\
\text { Volume } \\
\text { Liter }\end{array}$ & $\begin{array}{l}\text { ITS } \\
\text { Weight } \\
\text { Kilogram }\end{array}$ & $\begin{array}{l}\text { Metric Units are in } 10 \text { 's } \\
1000 \text { millimeters }=100 \text { centimeters }=1 \text { meter } \\
1000 \text { meters }=1 \text { kilometer }\end{array}$ \\
\hline Customary & $\begin{array}{l}\text { Inch } \\
\text { Foot } \\
\text { Yard } \\
\text { Rod } \\
\text { Mile }\end{array}$ & $\begin{array}{l}\text { Teaspoon } \\
\text { Tablespoon } \\
\text { Cup } \\
\text { Pint } \\
\text { Quart } \\
\text { Gallon }\end{array}$ & $\begin{array}{l}\text { Grain } \\
\text { Ounce } \\
\text { Pound } \\
\text { Ton }\end{array}$ & $\begin{array}{l}\text { T meter } \cong 1.1 \text { yords } \\
1 \text { liter } \cong 1.1 \text { quarts } \\
\text { l kilogram } \cong 2.2 \text { pounds } \\
1 \cong \text { opproximatel }\end{array}$ \\
\hline
\end{tabular}

US. DEPARTMENT OF COMMERCE Not Bureau of Stondards Washingian. D C. 20234

NBS Special Publicalıan 378 Issued December 1972

for sole by the Superinlendent of Documenis, U.S. Government Printing Order by SD Cotolog No. C13.10:376) Price 25 cents.

COMPARE METRIC AND CUSTOMARY UNITS

\begin{tabular}{|c|c|c|c|}
\hline Metric & $\begin{array}{l}\text { Length } \\
\text { Meter }\end{array}$ & $\begin{array}{l}\text { Valume } \\
\text { Liter }\end{array}$ & $\begin{array}{l}\text { Mass } \\
\text { (Wolght) } \\
\text { Kilogram }\end{array}$ \\
\hline Customary & $\begin{array}{l}\text { Inch } \\
\text { Foot } \\
\text { Yard } \\
\text { Rod } \\
\text { Mile }\end{array}$ & $\begin{array}{l}\text { Teaspoan } \\
\text { Tablespoon } \\
\text { Cup } \\
\text { Pint } \\
\text { Quart } \\
\text { Gallon }\end{array}$ & $\begin{array}{l}\text { Grain } \\
\text { Ounce } \\
\text { Pound } \\
\text { Ton }\end{array}$ \\
\hline
\end{tabular}

Metric Units are in 10's

1000 millimeters $=100$ centimeters $=1$ mete 1000 meters $=1$ kilometer

T meter $\cong 1.1$ yards

1 liter $\equiv 1.1$ quarts

l kilogram $\cong 2.2$ pounds

( $\cong$ approximate)

NOTE: Scales on reverse side are approximate.
U.S. DEPARTMENT OF COMMERCE U.S. DEPARTMENT OF Standards National Bureau of Stand

NBS Special Publication 376 NBS Special Publlcat
Issued January 1979

For sale by the Superintendent of Office, Washington, D.C. 20402

Stock No. 003-003-01080-4 Price 60 cents
$\$ 9.90$ per 100 coples
Approximate Colversions

from Metric Measures

Symbol When You Know Multiply by To Find Symbol

\begin{tabular}{lllll}
\multicolumn{5}{c}{ LENGTH } \\
\hline $\mathrm{mm}$ & millimeters & 0.04 & inches & in \\
$\mathrm{cm}$ & centimeters & 0.4 & inches & in \\
$\dot{m}$ & meters & 3.3 & feet & $\mathrm{ft}$ \\
$\mathrm{m}$ & meters & 1.1 & yards & $\mathrm{yd}$ \\
$\mathrm{km}$ & kilometers & 0.6 & miles & $\mathrm{mi}$ \\
\hline \multicolumn{4}{c}{ AREA } \\
\hline $\mathrm{cm}^{2}$ & square centimeters & 0.16 & square inches & $\mathrm{in}^{2}$ \\
$\mathrm{~m}^{2}$ & square meters & 1.2 & square yards & $\mathrm{yd}^{2}$ \\
$\mathrm{~km}^{2}$ & square kilometers & 0.4 & square miles & $\mathrm{mi}^{2}$ \\
$\mathrm{ha}$ & hectares & 2.5 & acres & \\
& \multicolumn{1}{c}{$\left(10000 \mathrm{~m}^{2}\right)$} & & &
\end{tabular}

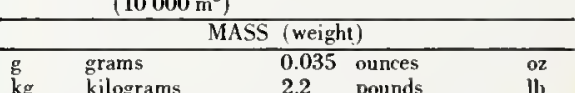

$\mathrm{kg} \quad$ kilograms $\quad 2.2$ pounds

$t$ metricton $(1000 \mathrm{~kg})$

\begin{tabular}{llcll}
\hline \multicolumn{5}{c}{ VOLUME } \\
\hline $\mathrm{mL}$ & milliliters & 0.03 & fluid ounces & $\mathrm{fl} \mathrm{oz}$ \\
$\mathrm{mL}$ & milliliters & 0.06 & cubic inches & $\mathrm{in}^{3}$ \\
$\mathrm{~L}$ & liters & 2.1 & pints & $\mathrm{pt}$ \\
$\mathrm{L}$ & liters & 1.06 & quarts & $\mathrm{qt}$ \\
$\mathrm{L}$ & liters & 0.26 & rallons & $\mathrm{gal}$ \\
$\mathrm{m}^{3}$ & cubic meters & 35 & cubic feet & $\mathrm{ft}^{3}$ \\
$\mathrm{~m}^{\mathrm{s}}$ & cubic meters & 1.3 & cubic yards & $\mathrm{yd}^{3}$ \\
\hline
\end{tabular}

\section{$\mathrm{m}^{8} \quad$ cubic meters}

$$
\begin{array}{llcl}
\hline \multicolumn{4}{c}{\text { TEMPERATURE (exact) }} \\
\hline{ }^{\circ} \mathrm{C} & \begin{array}{l}
\text { degrees } \\
\text { Celsius }
\end{array} & \begin{array}{c}
9 / 5(\text { then degrees } \\
\text { add } 32)
\end{array} & { }^{\circ} \mathbf{F} \text { Fhrenheit }
\end{array}
$$

For sale by the Superintendent of Documents, U.S. Government Printing Office, Washington, D.C. 20402. Price 25

cents domestic post-paid; add $1 / 4$ additional for foreion mailing. Stock Number 0303.0168. Catalog No. C13.10. $365 / 2$.

\begin{tabular}{|c|c|c|c|c|}
\hline \multicolumn{5}{|c|}{ Approximate Conversions } \\
\hline Symbol & When You Know, Mul & Itiply by & To Find & Symbol \\
\hline \multicolumn{5}{|c|}{ LENGTH } \\
\hline $\mathrm{mm}$ & millimeters & 0.04 & inch & in \\
\hline $\mathrm{cm}$ & centi & 0.4 & incl & in \\
\hline m & & 3.3 & & \\
\hline m & mete & 1.1 & yard & yd \\
\hline & kilom & 0.6 & & $\mathrm{mi}$ \\
\hline \multicolumn{5}{|c|}{ AREA } \\
\hline $\mathrm{cm}^{2}$ & square centimeters & 0.16 & squar & $\mathrm{in}^{2}$ \\
\hline $\mathrm{m}^{2}$ & square meters & 1.2 & squar & $y d^{2}$ \\
\hline $\mathrm{km}^{2}$ & square kilometers & 0.4 & square mi & $\mathrm{mi}^{2}$ \\
\hline ha & $\begin{array}{l}\text { hectares } \\
\qquad\left(10000 \mathrm{~m}^{2}\right)\end{array}$ & 2.5 & & \\
\hline \multicolumn{5}{|c|}{ MASS (weight) } \\
\hline & grams & 0.035 & ounc & oz \\
\hline $\mathrm{kg}$ & kilograms & 2.2 & & Ih \\
\hline & $\begin{array}{l}\text { metric ton } \\
\quad(1000 \mathrm{~kg})\end{array}$ & 1.1 & tons & \\
\hline \multicolumn{5}{|c|}{ VOLUME } \\
\hline $\mathrm{mL}$ & milliliters & 0.03 & fluid ounces & $\mathrm{floz}$ \\
\hline $\mathrm{mL}$ & ters & 0.06 & & in $^{2}$ \\
\hline $\mathrm{L}$ & liters & 2.1 & pints & $\mathrm{pt}$ \\
\hline$\overline{\mathrm{L}}$ & & 1.06 & & \\
\hline $\mathrm{L}$ & liters & 0.26 & gallons & gal \\
\hline $\mathrm{m}^{3}$ & cubic meters & 35 & cubic feet & $\mathrm{ft}^{3}$ \\
\hline & cubic meters & 1.3 & cubic yards & $\mathrm{yd}^{2}$ \\
\hline \multicolumn{5}{|c|}{ TEMPERATURE (exact) } \\
\hline & degrees 9 & $\begin{array}{l}9 / 5(t \\
\text { add } 3\end{array}$ & $\begin{array}{l}\text { degrees } \\
\text { Fahrenhe }\end{array}$ & ${ }^{\circ} \mathrm{F}$ \\
\hline
\end{tabular}

$\star$ GPO : $1976 \quad 0.207 .401$
For sale by the Superintendent of Documents, U.S. Government Printing Office, Washington, D.C. 20402. Price 25 cents domestic post-paid; add $1 / 4$ additional for foreign mailing. Stock Number 0303-0168. Catalog No. Cl3.10: $365 / 2$.

$\star$ GPO : 1976 O - 207-401 
Fellow American:

This Nation is now embarked on a changeover to the metric system of measurement. When the President signed the Metric Conversion Act, on December 23, 1975, the United States adopted a policy of encouraging a voluntary changeover to the metric system of weights and measures.

The material included in this package is designed to help us make that changeover as easily and painlessly as possible. As you look over these brochures and charts, you will see that in our everyday lives we will be dealing with four basic units of measurement: meter, liter, gram and degree Celsius. All of these units may be equated or 'translated' to our customary units of measurement: yard, quart, ounce and degree Fahrenheit. The important thing to remember is that eventually translation will not be necessary, because metric is simply a new language for communicating measurement information. Thus, it is my hope that this package will help you learn to 'speak' metric with ease and fluency.

Since its establishment in 1901, the National Bureau of Standards has promoted accuracy and uniformity in our Nation's measurement system. The countless measurements made every day in our homes, offices and factories can be traced ultimately to precision standards maintained by NBS.

It has been increasingly evident over the past 30 years that the metric system is the measurement language preferred by most nations. Recognizing this fact, the Congress in 1968 asked the National Bureau of Standards to undertake a comprehensive study of the metric system and make recommendations for national policy. As a result of this NBS study, the Congress began the legislative process which culminated in the Metric Conversion Act of 1975 .

I am confident that Americans will adapt quickly and easily to the metric system. This will bring us into closer harmony with the rest of the world and make it easier for us to do business with other nations.

Sincerely,

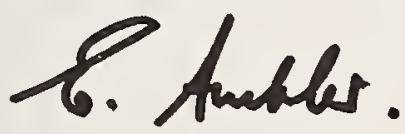

Ernest Ambler

Acting Director 



\section{AMERICA}
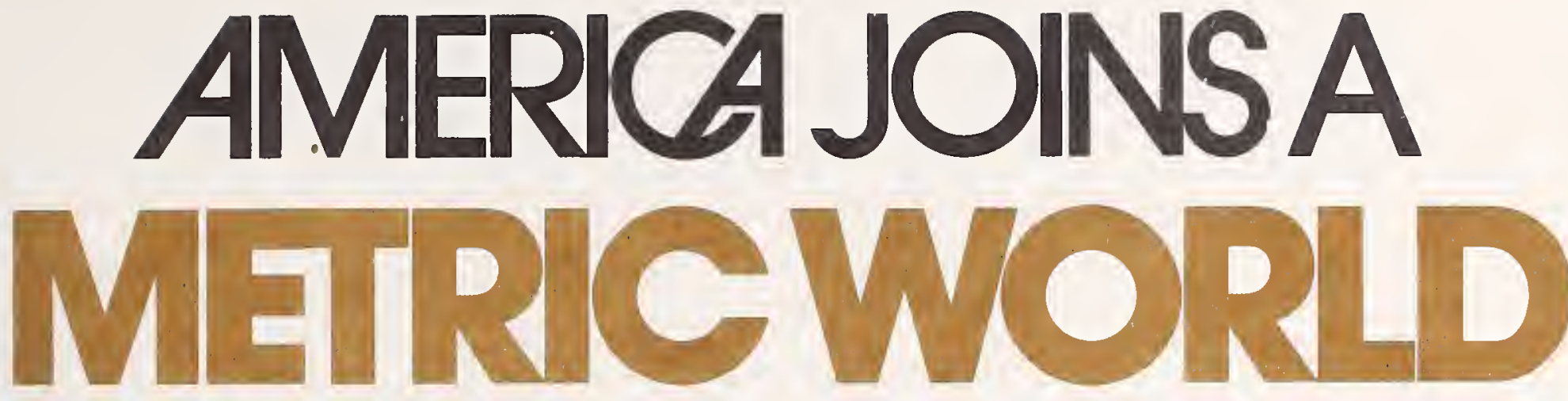

"It is therefore declared that the policy of the United States shall be to coordinate and plan the increasing use of the metric system in the United States and to establish a United States Metric Board. ..' (Metric Conversion Act of 1975)

0 N December 23, 1975, President Ford signed into law the Metric Conversion Act, establishing for the first time a national policy in support of metric measurement and ending a dilemma that had continued throughout the entire history of the Republic.

George Washington had raised the issue of a more uniform system of weights and measures in his first message to Congress on January 8, 1790. John Adams and Thomas Jefferson became strong advocates of that idea, speaking favorably of the recentlydeveloped French metric system.

Instead, the young Nation followed the tradition inherited from the British, the "customary" system of measurement. In 1875, the United States committed itself to metric by signing an international agreement, the Treaty of the Meter. This treaty was followed more in the breach than the observance. Inches, not meters, continued to reign supreme at home, although one result was that, ever since 1893, our national measurement standards have been metric.

Now at last, with the signing of the new law, the dilemma has been resolved through a national policy of coordinating the increasing use of metric in this country on a voluntary basis. The impetus for such a policy has come from our business community, which has been gradually adopt- ing metric over the last decade. Our schools have also begun to emphasize metric, and it is apparent that the country would have drifted through metrication in an uncoordinated way unless action had been taken at the national level.

The Metric Conversion Act of 1975 created a U.S. Metric Board, appointed by the President with the advice and consent of the Senate. The Eoard consists of 17 members representing the various economic sectors affected by the metric changeover. These include engineering, science, large and small business, organized labor, education, manufacturing, consumers, weights and measures officials, State and local governments, and the construction industry.

The Board's function is to devise and carry out a broad program of planning, coordination and public education consistent with other national policies and interests. This legislative action is, in part, the result of the comprehensive, 3-year study performed by the National Bureau of Standards for the Secretary of Commerce and submitted to the Congress in July 1971. This study recommended that the United States change to the metric system deliberately and carefully through a coordinated program. The purpose of the Metric Conversion Act of 1975 is to accomplish this goal. It allows the development of a rational plan for a voluntary changeover. In this way, metric will come as the various sectors of our economy are ready for it-and not before.

In fact, metric has come to many sectors of American life over the past several years at an ever accelerating but erratic pace. Industry continues to take the lead in the private sector. At least 37 major corporations have announced policies to convert their operations. The total sales of these companies exceed $\$ 130$ billion, and the list contains four of the Nation's 10 largest firms. Some of the first metric-minded corporations included: Caterpillar Tractor, Chrysler, Ford Motor Company, General Motors, IBM, International Harvester, Minnesota Mining and Manufacturing, Travelers Insurance, and Xerox.

Whereas until just recently the metric changeover was found predominately among manufacturers with overseas interests, some of America's largest retailers have gotten on the bandwagon. Sears, Roebuck and Company, Montgomery Ward and Company, and J. C. Penney are notable leaders in this category.

As mentioned, another sector of American life that has seen growing use of the metric system is education. School systems in all 50 states have turn page 

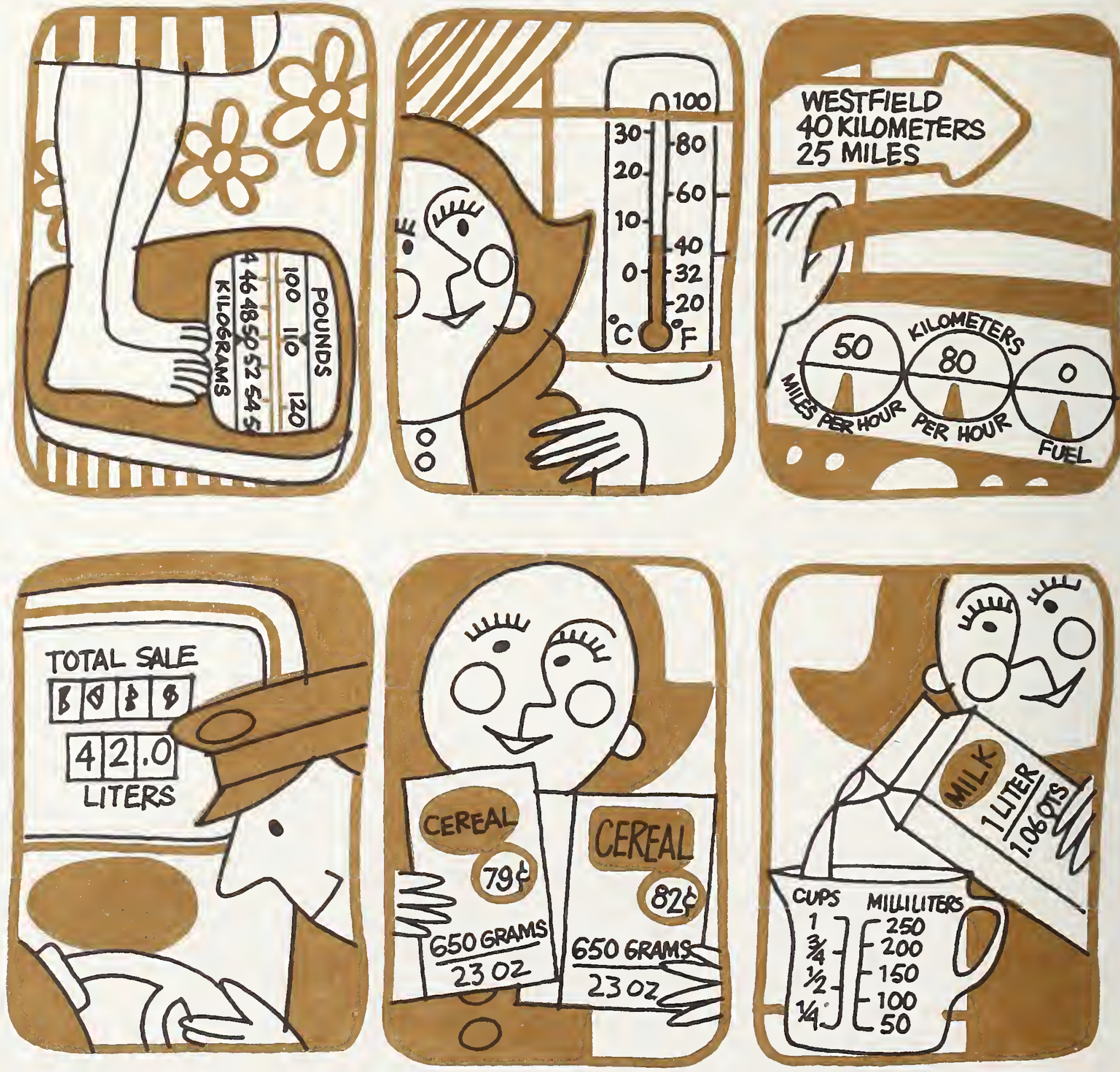
underway some type of metric activity. These activities include: making metric workshops available to teachers, providing guidelines for training of teachers, producing educational television programs, and specifying the use of metric as the primary measurement language in new textbook purchases. In more than 30 states this "trend" is reinforced by State legislation or by State school board action. In Maryland, for example, the State School Board adopted a resolution in August 1973, calling for schools to be totally metric by 1980. The State Department of Education has a well developed plan and a timetable to meet this objective.

The Congress recognized the schools' swing to metric in the Education Amendments of 1974, P.L. 93380, which authorized a Metric Education Program to be managed by the U.S. Office of Education. Appropriated funds support model and demonstration projects aimed at improving the quality and extent of metric education. The Metric Conversion Act of 1975 also recognizes the need to train teachers and introduce metric into the Nation's classrooms. A representative of the educational community is included on the U.S. Metric Board.

The States are not limiting themselves just to metric education in schools. At the time of the signing of the bill a total of 13 states had erected some metric road signs; Georgia, Maine, and California had established State metric conversion commissions; California's Division of Oil and Gas had switched to using only metric units; Pennsylvania and Florida had cooperated with the Sun Oil Company in a pilot test to sell gasoline by the liter; North Dakota had adopted metric signs for its State parks; and bills to coordinate metric conversion had been introduced into 18 State legislatures.

State and local weights and measures officials through their organization, the National Conference on Weights and Measures, have begun planning for the effects of metric changeover on commercial weights and measures activities. Working with this group, for which the National Bureau of Standards maintains the Secretariat, NBS has already equipped each State with a set of metric standards and laboratory instruments that are NBS-certified as to accuracy.

On the Federal level, various metrication efforts have been underway to meet immediate needs. Since publication of the metric study in 1971, NBS has maintained a Metric Information Office. The volume of inquiries and requests have grown steadily. In one 6-month period in 1975, NBS answered 20,000 letters and 2,000 telephone calls for information. More than 100,000 NBS Metric Kits have been prepared and are being sold through the Government Printing Office. A national speakers bureau was formed to meet a need for metric information from civic, homemaker, PTA, and other groups.

The U.S. Metric Board assumes many of NBS' public information functions, but the Bureau will continue to provide international metric coordination through the General Conference on Weights and Measures created by the Treaty of the Meter. It is at this Conference that the components of the modernized metric system, International System of Units (SI), are agreed upon by the participating nations. The Bureau will also retain responsibility for maintaining the national measurement system, coordinating metrication with State weights and measures officials, and through its interaction with consumer, business, and scientific groups, assist the nation in the changeover to metric.

Activity in other Federal agencies is underway:

- The Department of Defense issued a policy statement in June 1975 that it would use metric when feasible, practical, and efficient.

- The Treasury Department, at the request of industry, has held hearings on new regulations that would specify metric-sized bottles for distilled alcoholic beverages. There was no opposition to these regulations at the hearings. Similar regulations have already been approved for the wine industry.

- The National Aeronautics and Space Administration has been using metric units extensively for several years.

- The Interagency Committee on Standards Policy, chaired by the Department of Commerce, has established a Metrication Subcommittee to help coordinate Federal agency metric activities.

- Other Federal agencies which have initiated some metric activity-ranging from forming committees to using metric publications and signsinclude the Department of Interior, Federal Highway Administration, Federal Housing Administration, Department of Health, Education and Welfare, National Weather Service, Maritime Administration, Forest Service, National Park Service, Agriculture Department, Patent and Trademark Office, Environmental Protection Agency, and Federal Communications Commission. 
Just why is the United States going metric after having lived with the English system for more than 200 years? The answer is quite simple: We cannot afford not to.

All of our major trading partners have either gone metric or are in the process of doing so. In fact, the only countries still not committed are Brunei, Burma, Liberia, and Yemen. Before the 1975 Act, we literally were an island in a metric sea. The British Commonwealth countries, with whom we shared the pounds-quarts-yards system for so long, have all committed themselves to metric. This includes Canada, our closest neighbor, which has an unofficial goal of being all-metric by 1980 .

Our industrial community has also seen the necessity for metric conversion as markets for American goods and services expand overseas. In order to do effective business abroad, these large corporations have had to dualdimension their products, create a separate production capability to turn out metric products for export, or abandon customary design altogether and produce all products in metric dimensions. More and more corporations are doing the latter.

We are also seeing some barriers being erected to U.S. products in customary dimensions. The Common Market in 1971 adopted a directive that requires all exporters to the nine Common Market nations to indicate the dimensions of their products in metric units by 1978. Dual dimensioning will be allowed only if determined not to be confusing, with each nation to judge compliance separately. This action could bar American goods from these markets or could lead to costly relabeling of products.

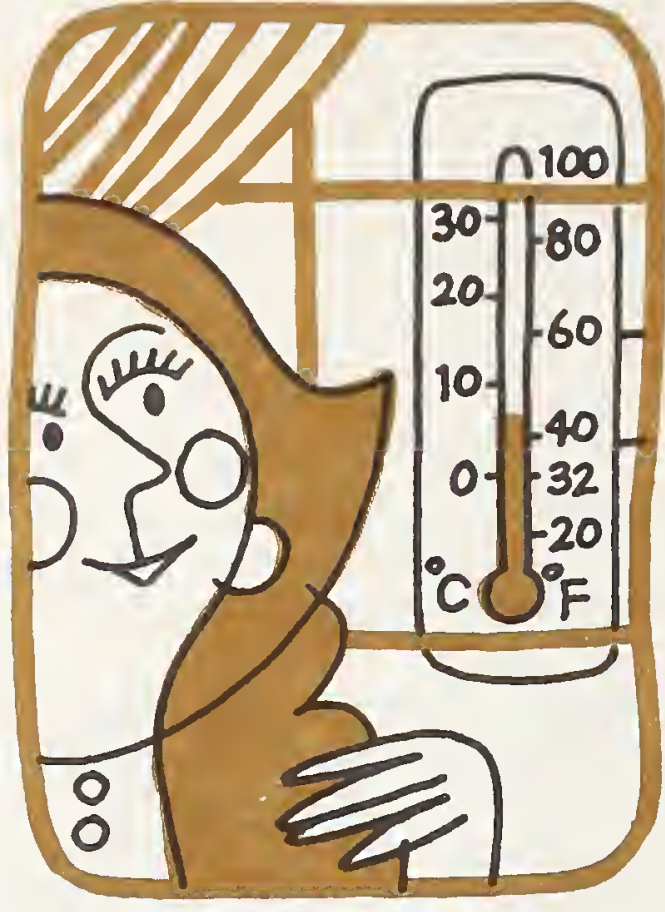

Ultimately, it is in our national best interest to convert to metric. And there is a decided advantage for American industries that "go metric." In addition to opening up new markets, the benefits of standardization under the metric system will be realized in reduced inventories. Manufacturers will not have to keep on hand as many product lines to correspond with various size requirements. For example, the Treasury Department's new regulations, scheduled to go into effect in 1979, will reduce the number of "standardized" wine bottles offered in this country from 16 to seven. The U.S. fastener industry will replace 59 customary sizes with 25 metric sizes for threaded fasteners.

A question frequently asked is what effect this changeover will have on the average citizen. Everyone will be affected, but the disruption in normal living will be minimal. Experience in other countries suggests that the American public will have little trouble in mastering the few metric units it will need for everyday living.

Most persons will need to know only three measurement units-meters, liters and grams. A meter is a unit of length slightly longer than a yard; a liter is a measure of volume and is a little larger than a quart; a gram is a unit of weight about as heavy as a paper clip. Because gram is such a small unit, it is easier to think about the kilogram (1000 grams), which amounts to a little more than 2 pounds.

Metric is a decimal system that uses multiples of 10, as does our currency system. Each basic metric unit can be multiplied or divided by factors of 10 to get larger and smaller units. These multiples and submultiples are indicated by prefixes such as kilo (one thousand), centi (one hundredth) and milli (one thousandth). Thus a kilometer means 1000 meters, a centimeter is $1 / 100$ of a meter and a millimeter is $1 / 1000$ of a meter.

Temperatures in metric are measured on the Celsius scale rather than Fahrenheit scale. (Celsius was formerly called Centigrade.) In the Celsius scale, water boils at 100 degrees and freezes at 0 degrees. This is easier to remember than in Fahrenheit, where water boils at 212 degrees and freezes at 32 degrees.

The changeover will create minimal confusion. Initially most items such as roadsigns and consumer goods will be labeled in both customary and metric dimensions. This is already happening with some automobile speedometers that are dually labeled. In the supermarket, canned goods will be labeled in both ounces and grams for a time (many are already) and eventually in grams alone.

The Metric Conversion Act of 1975 and the U.S. Metric Board which that Act creates will provide the necessary focal point for a smooth, coordinated conversion to the metric system in this country. No one will be forced to "go metric." But gradually, as each of our country's economic sectors see the desirability of going metric in a rational way, we will become a predominately metric nation. 
The United States joined the worldwide trend toward adoption of the metric system of measurement with the enactment of the Metric Conversion Act of 1975. Several years prior to that action, the Congress asked the National Bureau of Standards to make a thorough investigation of the metric question. That investigation involved public hearings and surveys of almost every activity of our society-from education and the consumer to international trade and national security. The findings are given in the following summary and 12 detailed reports:

A METRIC AMERICA: A DECISION WHOSE TIME HAS COME (Summary Report to the Congress). D. V. DeSimone, NBS SP 345, 190 pages (July 1971), SD Stock No. SN 003-003-00884-2.

INTERNATIONAL STANDARDS. R. D. Huntoon et al., NBS SP345-1, 145 pages (Dec. 1970), SD Stock No. SN 003-003-00731-5.

FEDERAL GOVERNMENT: CIVILIAN AGENCIES. R. E. Clark and J. M. Tascher, NBS SP 345-2, 324 pages (July 1970), SD Stock No. SN 003003-00824-9.

COMMERCIAL WEIGHTS AND MEASURES. S. L. Hatos, NBS SP 345-3, 109 pages (July 1971), SD Stock No. SN 003-003-00859-1.

THE MANUFACTURING INDUSTRY. L. E. Barbrow, Coordinator, NBS SP 345-4, 165 pages (July 1971), SD Stock No. SN 003-003-00825-7.

NONMANUFACTURING BUSINESSES. E. D. Bunten and J. R. Cornog, NBS SP 345-5, 192 pages (Aug. 1971), SD Stock No. SN 003-003-00898-2.

$\$ 2.70$

EDUCATION. B. D. Robinson, NBS SP 345-6, 209 pages (July 1971), SD Stock No. SN 003-003-00858-3.

THE CONSUMER. B. D. Rothrock, NBS SP 345-7, 146 pages (July 1971), SD Stock No. SN 003-003-00864-8.

INTERNATIONAL TRADE. G. F. Gordon, NBS SP 345-8, 181 pages, (Aug. 1971), SD Stock No. SN 003-003-00895-8.

U.S. METRIC STUDY INTERIM REPORT: DEPARTMENT OF DEFENSE. D.V. DeSimone, NBS SP 345-9, 132 pages (June 1971), (Order as com 71-50305 from the National Technical Information Service, 5285 Port Royal Rd., Springfield, VA. 22151.)

A HISTORY OF THE METRIC CONTROVERSY IN THE UNITED STATES C. F. Treat, NBS SP 345-10, 306 pages (Aug. 1971), SD Stock No. SN 003-003-00879-6.

ENGINEERING STANDARDS. R. D. Stiehler, NBS SP 345-11, 257 pages (July 1971), SD Stock No. SN 003-003-00835-4.

$\$ 3.20$

$\$ 1.75$

$\$ 1.95$

$\$ 2.15$

$\$ 2.30$

$\$ 1.75$

$\$ 2.10$

$\$ 5.50$

(from NTIS

only)

$\$ 3.05$

TESTIMONY OF NATIONALLY REPRESENTATIVE GROUPS. J. V. Odom, Editor, NBS SP 345-12, 174 pages (July 1971), SD Stock No. SN 003-003-00865-6. 
The National Bureau of Standards has compiled six useful items into a single official metric information kit which is available for sale. Priced items are also sold individually at the prices listed. Ordering information is on the back of this publication.

COMPLETE NBS METRIC KIT, NBS SP 410, SD Stock No.

$\$ 2.00$ per kit SN 003-003-01736-1.

$25 \%$ discount for 100 or more

Metric Conversion Card, NBS SP 365, SD Stock No.

SN 003-003-1068-5

For Good Measure (ruler), NBS SP 376, SD Stock No.

SN 003-003-1080-4.

Brief History of Measurement Systems with Chart of the Modernized Metric System, NBS SP 304A, SD Stock

$\$ 4.70$ per 100

No. SN 003-003-1713-2.

What About Metric?, NBS CIS 7, SD Stock No. SN 003-003-1688-8.

$\$ 4.70$ per 100

$\$ 5.70$ per 100

America Joins the Metric World, Reprinted from DIMENSIONS/

$\$ 23.50$ per 100 NBS (February 1976)

Not sold

NBS Metric Information (bibliography), NBS LC 1070

(includes chart "All You Need to Know About Metric") separately

Not sold separately

The following are other metric materials published by the National Bureau of Standards.

FACTORS FOR HIGH-PRECISION CONVERSION-U.S. CUSTOMARY AND METRIC UNITS. NBS LC 1071, 8 pages (July 1976).

See page 5

METRIC STYLE GUIDE (for the News Media). NBS LC 1069, 6 pages (September 1976).

See page 5

UNITS AND SYSTEMS OF WEIGHTS AND MEASURES. NBS LC 1035, 26 pages (1976).

See page 5

HOUSEHOLD WEIGHTS AND MEASURES. NBS SP 430, 2 pages (1975), SD Stock No. SN 003-003-01542-3.

$\$ .25$

THE INTERNATIONAL SYSTEM OF UNITS (SI). NBS SP 330, 43 pages (1974), SD Stock No. SN 003-003-01326-9.

WALL CHART OF THE MODERNIZED METRIC SYSTEM. NBS SP 304,1 page (1972), SD Stock No. SN 003-003-00079-5.

SUCCESSFUL EXPERIENCES IN TEACHING METRIC. NBS SP 441, 115 pages (1976), SD Stock No. SN 003-003-01568-7.

INTERNATIONAL BUREAU OF WEIGHTS AND MEASURES. NBS SP 420, 256 pages (1975), SD Stock No. SN 003-003-01408-7. 



\section{All You Will Meed to Know Ahout metrit} (For Vour Eueryday Life)

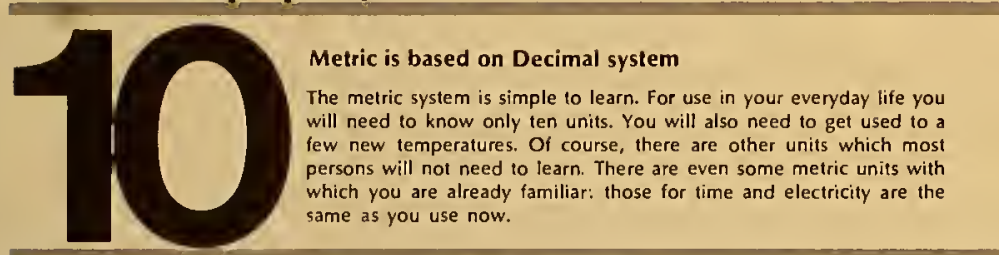

\section{Bhsit units}

METER: a little longer than a yard (about 1.1 yards)

LIJER: a little larger than a quart (about 1.06 quarts)

CRAM; a little more than the weight of a paper clip
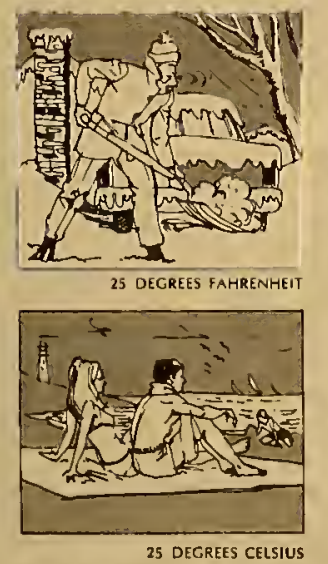

COMMON PREFIXES
(to be used with basic units)

milti: one-thousandth $(0.001)$

centi: one-hundredth $(0.01)$
kllo: one-thousand times $(1000)$

for example:

1000 millimeters $=1$ meter

1000 meters $=1$ kilometer

OTHER COMMONLY USED UNITS

millimeler: $\quad 0.001$ meter diameter of paper clip wire

centimeter; 0.01 meler a little more than the width of a paper

kllometer: $\quad 1000$ meters somewhat further than $1 / 2$ mille (about 0.5 mile)

$\begin{array}{ll}\text { kllogram: } & 1000 \text { grams a little more than } 2 \text { pounds (about } 2.2 \text { pounds) } \\ \text { mllitilter: } & 0.001 \text { Itter }\end{array}$

OTHER USEFUL UNITS

heclare: about $2 \frac{1}{2}$ acties

metrle ton: about one ion

WEATHER UNITS: FOR TEMPERATURE

FOR PRESSURE

hilopassals are used
100 kilopascals $=29.5$ inches ol $\mathrm{Hg}$ (14.5 psi)

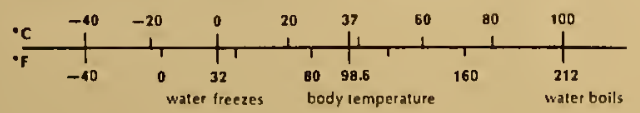

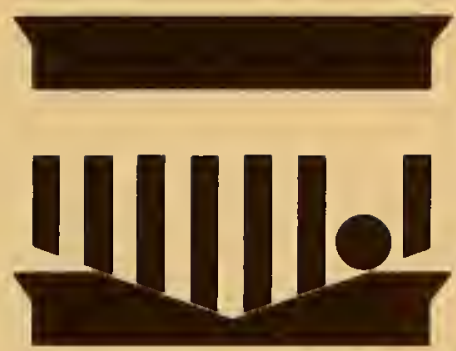

III|||||

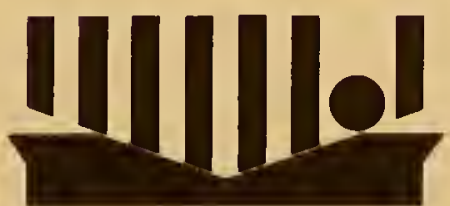

III||||| ||

|II|||||
Some References on

metric Informotion

Including a Chart on

All You Heed to Know hbout metric
NBS LC 1070

January 1977
Supersedes NES Special Publication 389

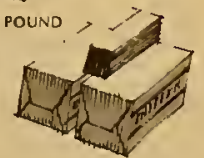

U.S. DEPARTMENT OF COMMERCE National Bureau of Standards 
American National Metric Council, 1625 Massachusetts Ave., NW., Washington, D.C. 20036. Established originally under the auspices of the American National Standards Institute to provide guidance to industrial and commercial segments of society.

American National Standards Institute (ANSI), 1430 Broadway, New York, N.Y. 10018. Publishes national standards and metric practice guides.

American Society for Testing and Materials, 1916 Race St., Philadelphia, PA 19103. Publishes assorted metric aids.

The Department of Defense has reproduced for free distribution two NBS metric items -the Modernized Metric System (wall chart in color) and the Metric Conversion Card (wallet card) - which are available upon request from your nearest Army school representative or Army reserve center.

National Council of Teachers of Mathematics, 1906 Association Drive, Reston, VA 22091. Publishes listings of organizations marketing metric material for educators.

National Science Teachers Association, 1201 Sixteenth St., NW., Washington, D.C. 20036. Publishes metric kit for teachers.

Science Service, 1719 N St., NW., Washington, D.C. 20009. Publishes "Things-ofScience" metric kit for students.

U.S. Metric Association, Sugarloaf Star Route, Boulder, CO 80302. Distributes educational material and publishes a quarterly newsletter, which is available to members.

National metric conversion boards in other countries can supply general information about conversion in their respective countries and can also provide referrals to other organizations therein. Their addresses are listed below.

Metric Conversion Board

18-24 Chandos Street

St. Leonards, N.S.W. 2065 Australia

Metric Advisory Board

P. O. Box 10-243

The Terrace

Wellington, New Zealand

South African Bureau of Standards

Private Bag X191

Pretoria, South Africa
Metrication Board

22 Kingsway

London WG2B 6LE England

Metrication Board of Zambia

P. O. Box 1968

Lusaka, Zambiå

Metric Commission

320 Queen Street

Ottawa K1A OH5 Canada 



U.S. DEPARTMENT OF COMMERCE / National Bureau of Standards 
The Unlted States jotned the worldwide trend toward adoption of the metric system

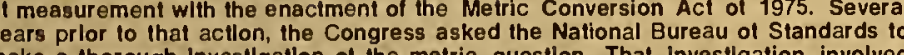

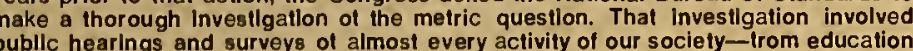

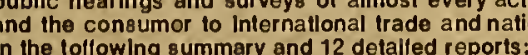

A METRIC AMERICA: A DECISION WHOSE TIME HAS COME (SUM-

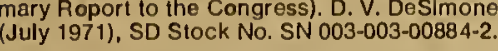

INTERNATIONAL STANDARSS. R. D. Huntoon et al., NBS SP345-1.
145 pagos (Dec. 1970), SD Slock No. SN O03-003-00731-5.

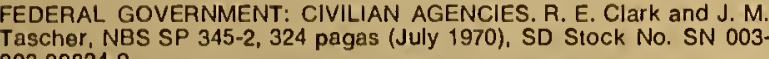

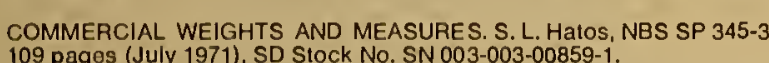
THE MANUFACTURING INDUSTRYY L. EE Bgrbrow, COordinator, NBS
SP 345-4, 165 Pages (July Y 1971), SD Stock No. SN 003-003-00825-7. NONMANUFACTURING BUSINESSES. E. D. Bunten and J. R. Cornoo EDUCATION. B. D. Robinson, NBS SP 345-6, 209 pages (July 1971),

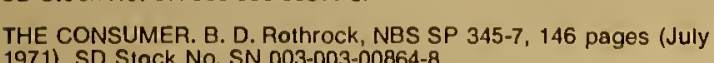
INTERNATTONAL TRADE. GG. F. Gordon, NES SP 345-8, 181 pages,
(Aug. 1971), SD SIOCK No. SN O03-003-00895-8.

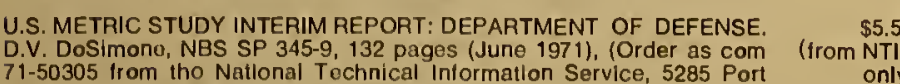

A HISTORY OF THE METRIC CONTROVERSY IN THE UNITED STATES
C.F. Troat, NBS SP 345-10, 306 Pages (AUg. 1971), SD Stock No. SN
O03-003-00879-6. ENGINEERING STANDARDS. R. D. SUlehler. NBS SP 345-11, 257 pages
(July 1971), SD Stock No. SN 003-003-00835-4.

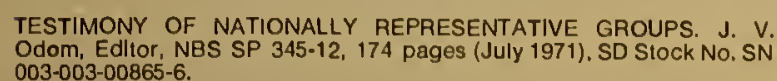

$\$ 2.70$

\section{IIIII|l.}

See Pege $S$ for Ordering Intormation

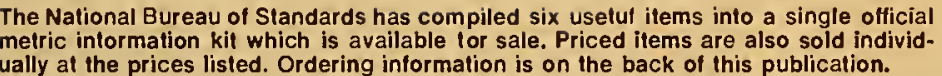
COMPLETE NBS METRIC KIT, NBS SP 410, SD Slock No.
SN 0 003-003-01736-1.

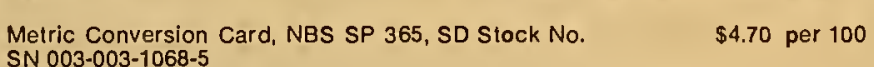

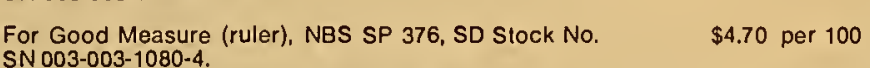
Brief History of Measurement Systems with Chart of
hre Modernized Metric System, NBS SP 304 , SD S Slock the Modernized Metric
No. SN $003-003-1713-2$.

What About Metric?, NBS CIS 7, SD Stock No. SN
$003-003-1688-8$.

${ }_{522.50}^{5}$ per 100

America Joins the Metric World, Reprinted from DIMENSIONS/ $\begin{gathered}\text { Not sold } \\ \text { NBS (Fepruarary 1976) }\end{gathered}$
separaly NBS Metric Intormation (bibliography), NBS LC 1070
(includes chart "All You Need to Know About Merric") The following are other metric materials published by the National Bureau of Stand-
ards.

FACTORS FOR HIGH-PRECISION CONVERSION-US. CUSTOMARY
AND METRIC UNITS. NBS LC 1071, 8 PaEgS (JUIY 1976 ). METRIC STYLE GUIDE (lor the News Media). NBS LC 1069, 6 pages
(Spplember 1976). UNITS AND SYSTEMS OF WEIGHTS AND MEASURES. NBS LC 1035.
26 pages (1976). HOUSEEOLD WEIGGTS AND MEASURES. NBS SP 430, 2 pages (1975),
SD SIock NO. SN O03-003-01542-3. THE INTERNATIONAL SYSTEM OF UNITS (SI). NBS SP 330, 43 pages
(1974), SD Stock NO. SN 003-003-01326-9. WALL CHART OF THE MODERNIZED METRIC SYSTEM. NBS SP 304, 1
page (1972), SD SIOCK NO. SN 003-003-00079-5. SUCCESSFUL EXPERIENCES IN TEACHING METRIC. NBS SP 441,
115 pages (1976), SD Stock NO. SN O03-003-01568-7. INTERNATIONAL BUREAU OF WEIGHTS AND MEASURES. NBS SP
420, 256 pages (1975), SD Stock No. SN O03-003-01400-7. See
page 5

See
page 5
5.25

\section{IIII||lol}

See Page 5 for Ordaring Informetlon

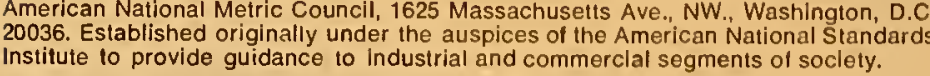

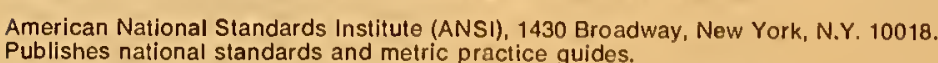
American Society for Testing and Materlals, 1916 Race St.. Philadelphla, PA 19103.
Publishes assorted metric aids.

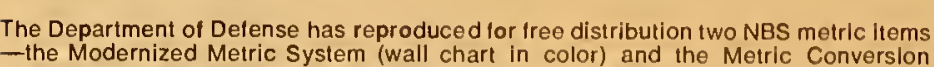

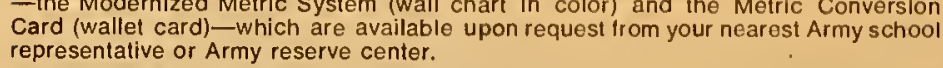
National Council of Teachers of Mathematlcs, 1906 Assoclation Drlve, Reston, VA
222091. Publilshes ilstings of organizatilions marketing mertic materlal tor oducalors. National Science Teachers Associallon, 201 Sixteenth St., NW., Washingtion, D.C.
20036 . Publishes metric kl tor teachers. Science, Service, $1719 \mathrm{~N} \mathrm{SLL,} \mathrm{NW.,} \mathrm{Washington,} \mathrm{D.C.} \mathrm{20009.} \mathrm{Publlshes} \mathrm{"Things-ol-}$
Science" merric kit tor students. U.S. Metric Association, Sugarloat Star Route, Boulder, CO 80302 . Distributes edu-
cational material and pubbishes a quarterly newsitetter, which is avaliable to mem-
bars

National metric converslon boards in other countrles can supply general Intormalion about conversion in their respective countriles and can also provide reterrals to
other organlzations therein. Thalr addresses are lls tod below.

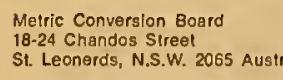

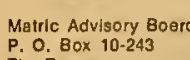

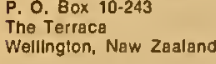

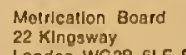

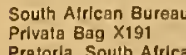

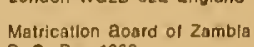

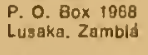

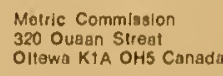





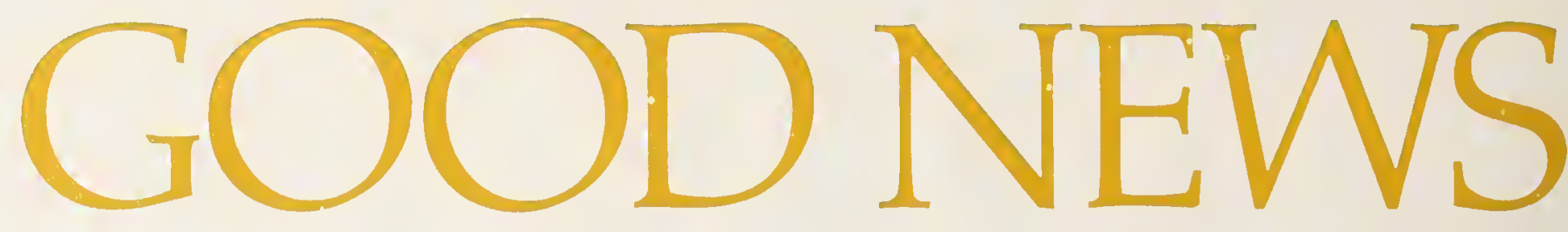

You use weights and measures every day of your life.

Without them, shopping, trade, recreation, and education would be in a state of hopeless confusion.

You learned the language of measurement so early that you have probably forgotten the day you first understood the meaning of "inch, foot, yard, and mile;" of "ounce, pound, and ton;" of "pint, quart, and gallon;" and that "100 ${ }^{\circ} \mathrm{F}$ " is uncomfortably hot, while " $30^{\circ} \mathrm{F}^{\prime}$ " is

uncomfortably cold. These are familiar units of the "customary" system of measurement.

After many years of debate, our nation recently embarked on a voluntary coordinated change from the customary system of measurement (the yard and pound) to the metric system of measurement (the meter and kilogram). On December 23, 1975, President Ford signed into law the Metric Conversion Act of 1975, which established for the first time a national policy to coordinate America's changeover to metric. Thus, the United States joined the worldwide trend toward a comparatively new system called the "modernized metric system" of measurement.

The names of the units in the metric system may sound strange to the American ear at first, but fortunately there are only a few words that have to be learned for everyday use. These are: the kilometer, meter, centimeter and millimeter for expressing length and distance; the liter and milliliter for capacity or volume; the kilogram, gram and metric ton for weight (mass); the degree Celsius for temperature; the kilopascal for pressure; and the hectare for area.

As we convert to the metric system, several units of measure that we currently use will not change. Time will continue to be measured in hours, minutes, and seconds; electric power will still be measured in watts; and our monetary system will remain the same.

The metric system is already being used in this country to a greater extent than most people realize. In international athletic competition, such as swimming and track and field events, length measurements are given in meters rather than in yards and feet. Our astronauts, from 
the surface of the moon, excitedly told a worldwide audience how far their rocket had landed from a lunar hill in meters. You see weights expressed in grams on more and more packaged items at the grocery store. And the trend is toward even greater use.

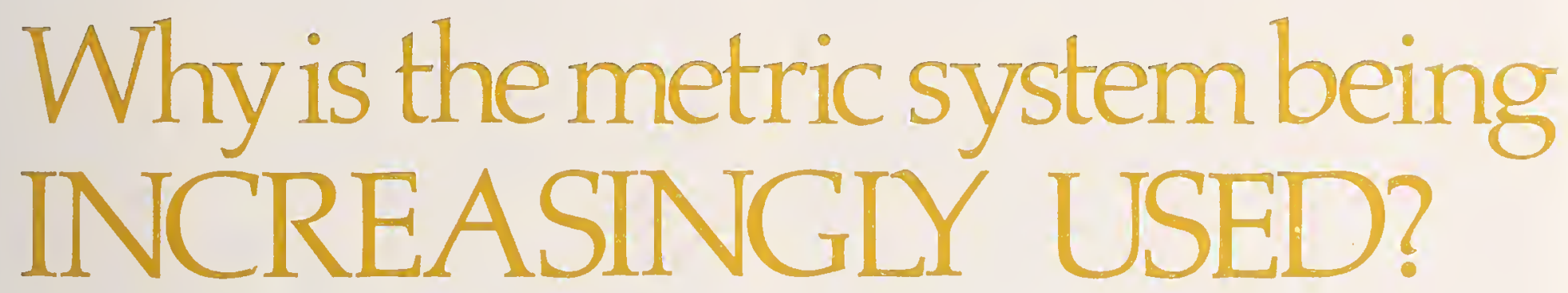

$\mathbf{T}$ he metric system is increasingly in use throughout the world for two reasons: it is a simple system, and it is a decimal system.

It is simple because each quantity, such as length (meter) or weight (gram), has its own unit of measurement, and no unit is used to express more than one quantity. In the customary system, however, pound can mean either force (as in pounds required to break a rope) or weight (as in a pound of sugar); and ounce can mean either volume (as the number of ounces in a quart) or weight (as the number of ounces in a pound).

The metric system is easier than the customary system to learn to use in solving problems that involve computation. This is because multiples of metric units are related to each other by the factor 10 . You have probably noticed that the names of metric units sometimes include prefixes such as milli, centi, and kilo as in milliliter, centimeter, and kilogram. These prefixes indicate multiples or submultiples of the units.

Consider the measurement of length-in the metric system any measure of length is expressed in meters or multiples of the meter. A centimeter is one hundredth of a meter; a millimeter is one thousandth of a meter; and a kilometer is one thousand meters. In the customary system, an inch is one thirty-sixth of a yard; a foot is one third of a yard; and a mile is 1760 yards.

The most commonly-used prefixes, and the multiplication factors they indicate, are given on the following pages. 


$$
\begin{aligned}
& 7 \text { WEIGHT } \\
& 1 \text { kilo } 1 \text { ra } 11 \text { = } 1000 \text { grams } \\
& 1 \text { hecto } 1 \text { ra }{ }^{*}=100 \text { grams } \\
& 1 \text { deka | ra } \|^{*}=10 \text { grams } \\
& 1 \text { g) } \\
& 1 \text { deci } 1 \mathrm{H}^{*}=0.1 \mathrm{gram} \\
& 1 \text { centi } 1 \text { ram }=0.01 \text { gram } \\
& 1 \text { milli j rall = } 0.001 \text { gram }
\end{aligned}
$$

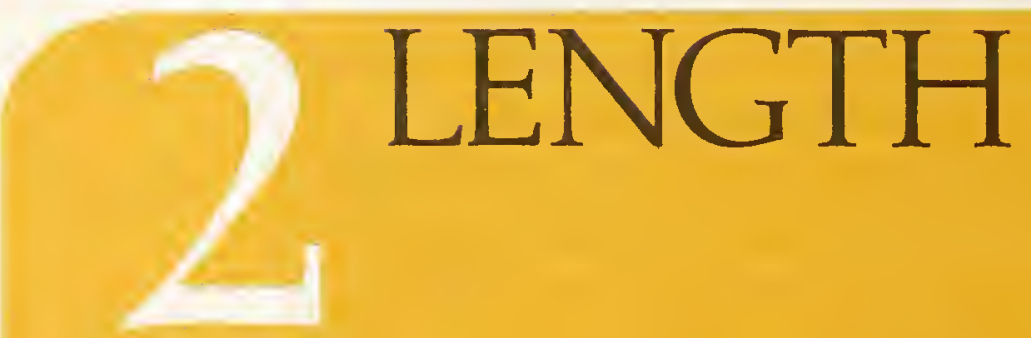

$$
\begin{aligned}
& 1 \text { kilomiter = } 1000 \text { meters } \\
& 1 \text { hecto } \\
& 1 \text { dekameter } * 10 \text { meters } \\
& 1 \text { metor = } 1 \text { meter } \\
& 1 \text { decimeter }{ }^{*}=0.1 \text { meter } \\
& 1 \text { centi ingter }=0.01 \text { meter } \\
& 1 \text { millimetor = } 0.001 \text { meter }
\end{aligned}
$$




\section{VOLUME}

\section{1 hecto ite* $=100$ liters 1 deka liter" $=10$ liters 1 litor $=1$ liter 1 deciliter ${ }^{*}=0.1$ liter 1 centi iter $* 0.01$ liter 1 milli itor = 0.001 liter}

* units not commonly used

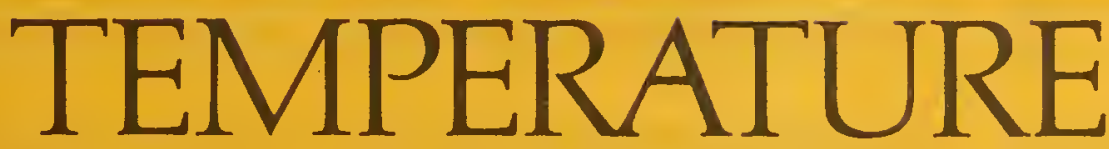

Prefixes are not commonly used with temperature measurements as they are with those for weight, length, and volume. Temperatures in degrees Celsius, as in the familiar Fahrenheit system, can only be learned through experience. The following may help to orient you with regard to temperatures you normally encounter.

$\begin{aligned} 0^{\circ} \mathrm{C} & \text { Freezing Point of Water }\left(32^{\circ} \mathrm{F}\right) \\ 10{ }^{\circ} \mathrm{C} & \text { A warm winter day }\left(50^{\circ} \mathrm{F}\right) \\ 20{ }^{\circ} \mathrm{C} & \text { A mild spring day }\left(68^{\circ} \mathrm{F}\right) \\ 30{ }^{\circ} \mathrm{C} & \text { Quite warm - almost hot }\left(86^{\circ} \mathrm{F}\right) \\ 37^{\circ} \mathrm{C} & \text { Normal body temperature }\left(98.6^{\circ} \mathrm{F}\right) \\ 40{ }^{\circ} \mathrm{C} & \text { Heat wave conditions }\left(104^{\circ} \mathrm{F}\right) \\ 100{ }^{\circ} \mathrm{C} & \text { Boiling point of water }\left(212^{\circ} \mathrm{F}\right)\end{aligned}$




\section{A visualcomparison of metric and customary units of measurement}

In the examples below, a visual comparison is made of the major units of the customary and metric systems, by using everyday quantities and sizes for purposes of illustration.
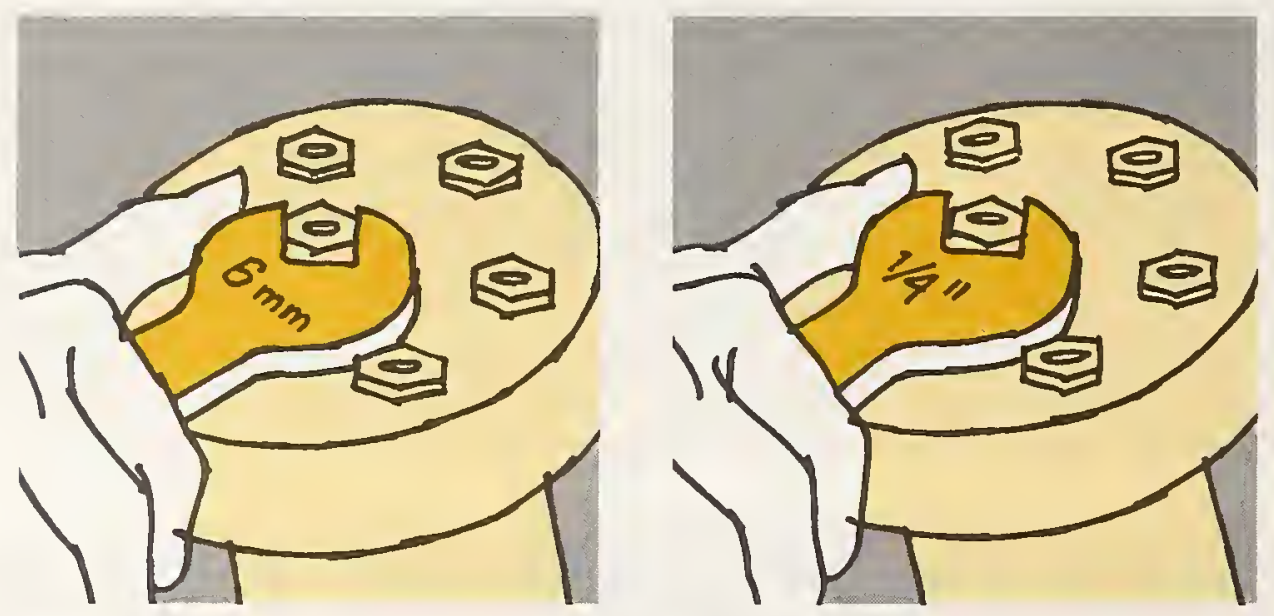

\section{Small linear dimensions}

For expressing small linear dimensions, such as wrench sizes, millimeters will replace inches. For example, a 6-mm wrench will be a more commonly-used size than a $1 / 4$-inch wrench
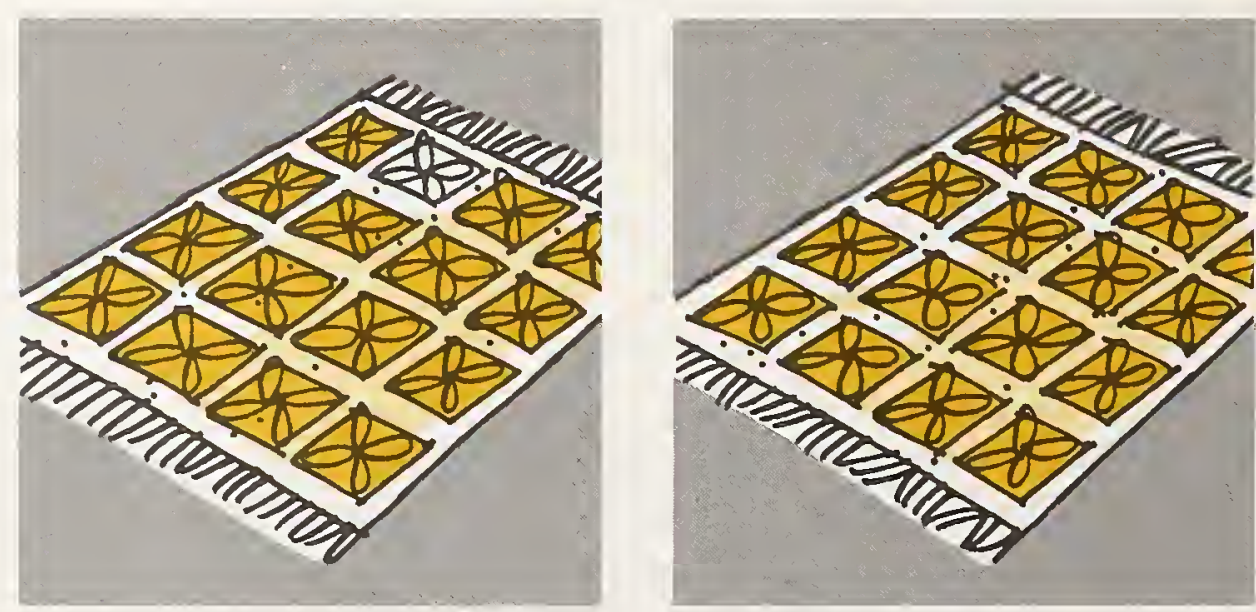

\section{Larger}

\section{linear dimensions}

In expressing larger sizes, the meter will replace both the foot and the yard. In the example shown, a $3 \times 4$ meter carpet will generally be sold rather than a $9 \times 12$ foot (or $3 \times 4$ yard) carpet.
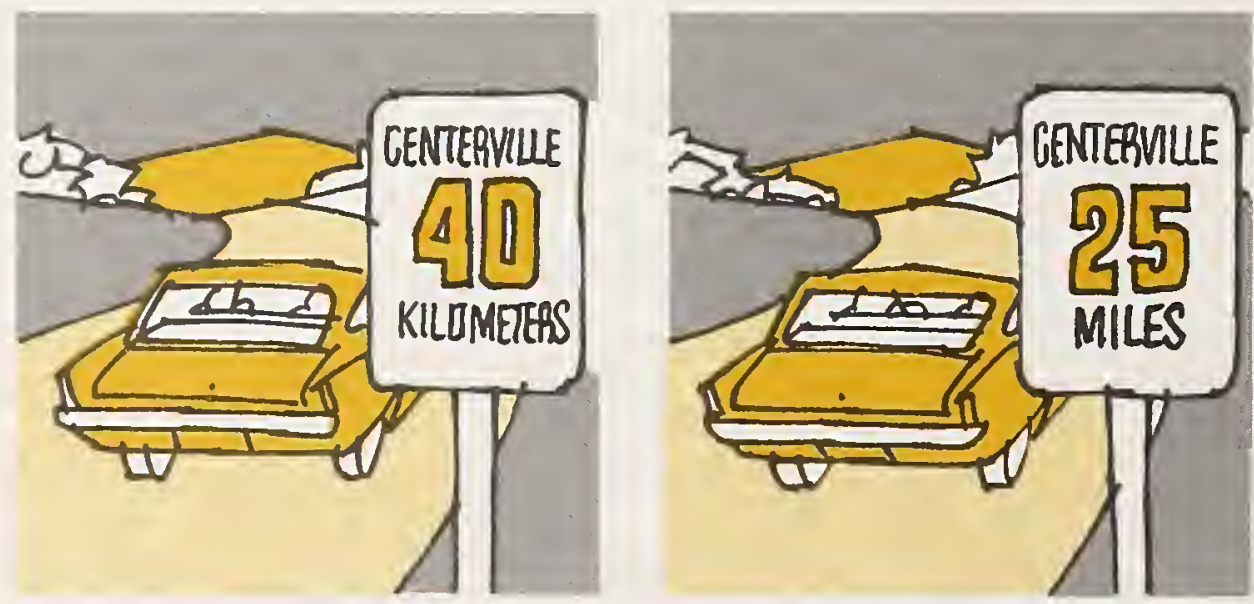

\section{Great}

\section{Distances}

The kilometer will replace the mile in expressing great distances, such as distances between cities. The example shows the replacement for a sign 25 miles from Centerville: it would read 40 kilometers. 

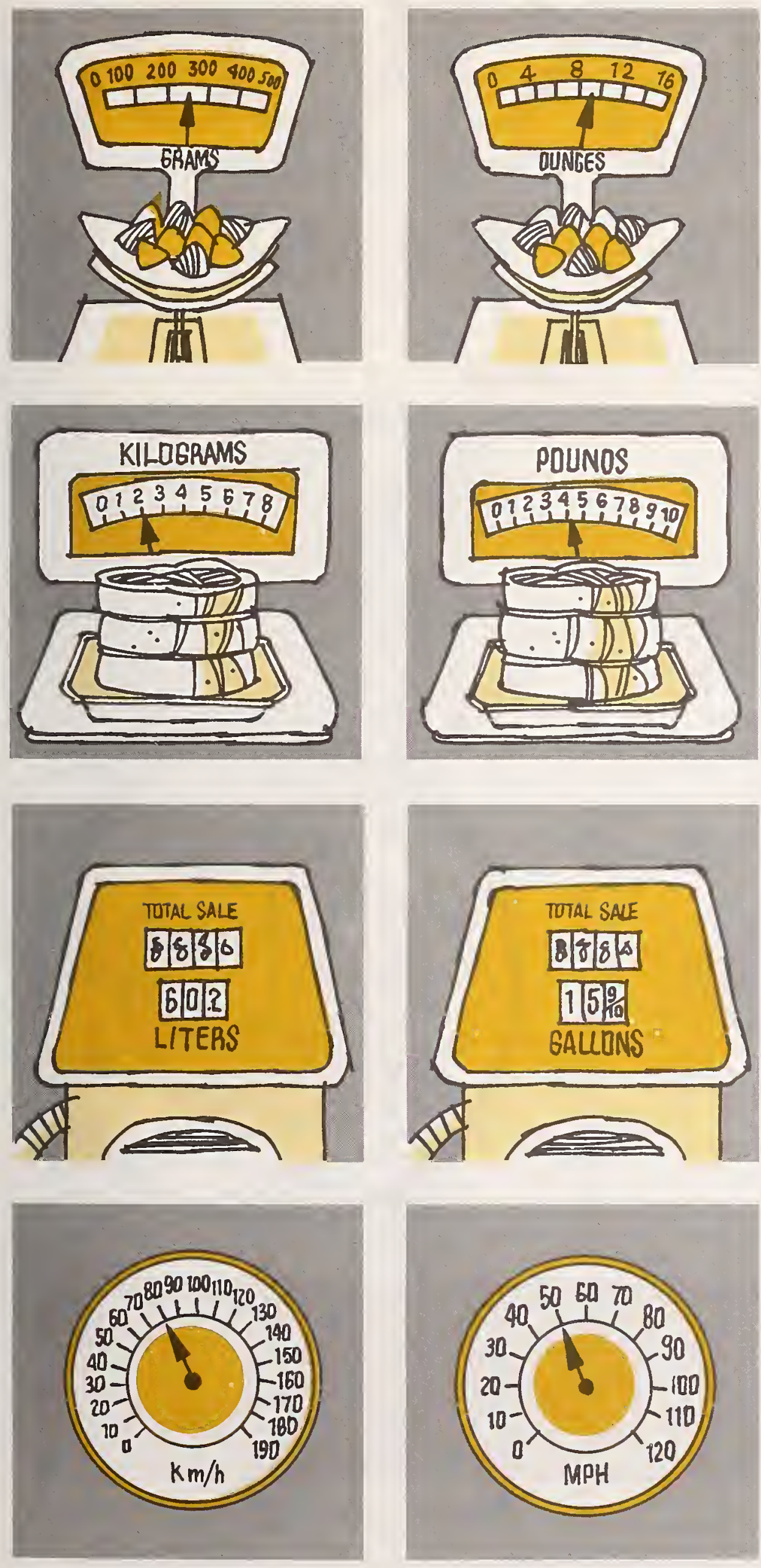

\section{Speed}

Our automobile speedometers will change from miles per hour to kilometers per hour as the speed limit signs on our highways are likewise changed. On the speedometers shown, an 80 kilometers per hour speed replaces 50 miles per hour. 

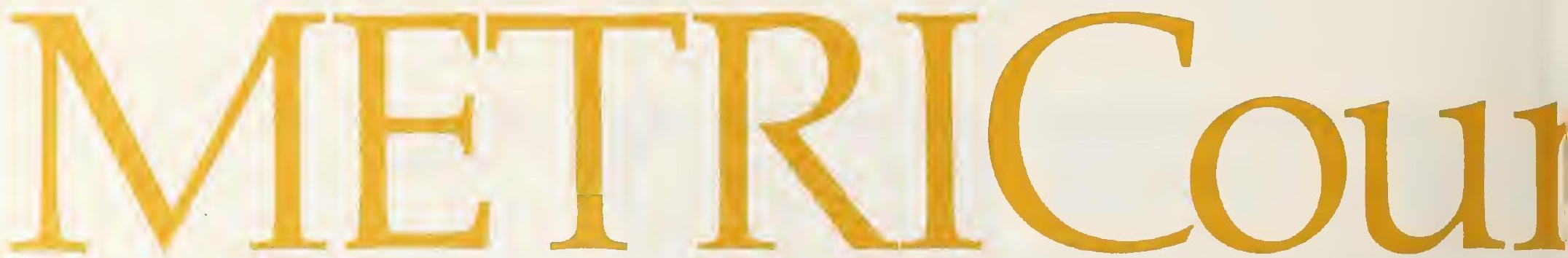

a handy guide for estimating the most common household measurements
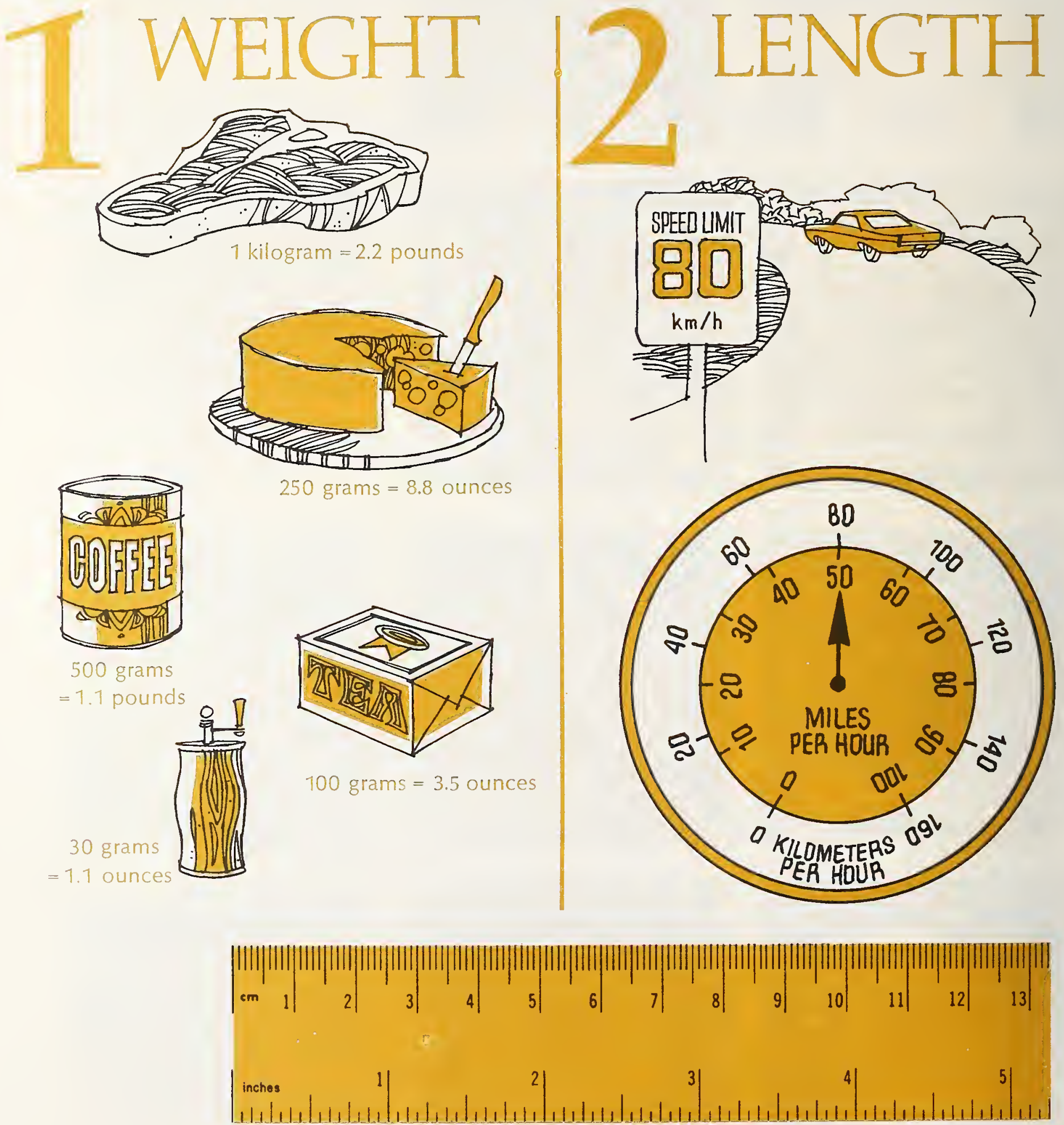


\section{VOLUME}
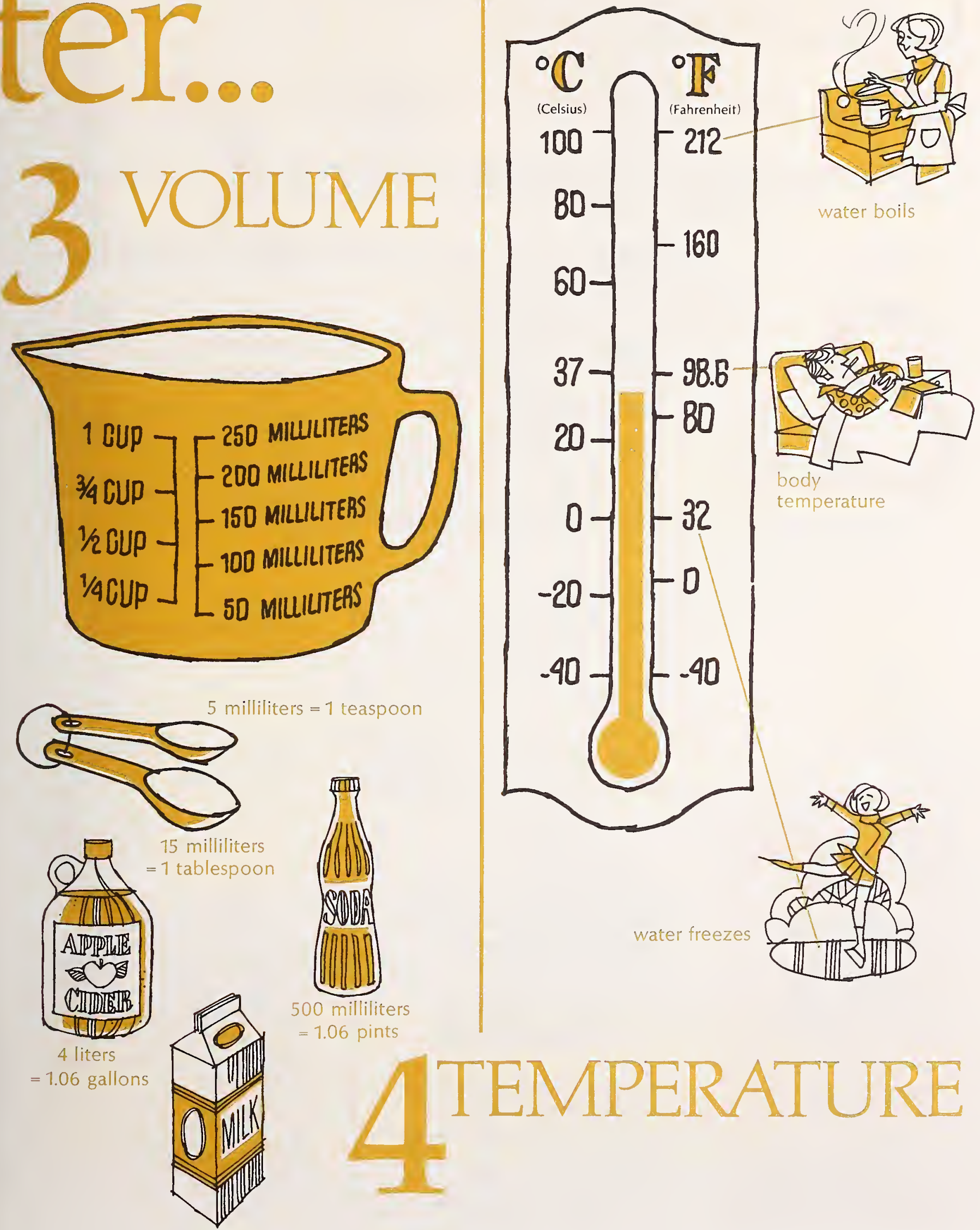

1 liter $=1.06$ quarts 


\section{Calculations \\ using metric and customary units}

The statement and solution of three everyday problems are given in both customary and metric units, providing a side by side comparison of the systems.

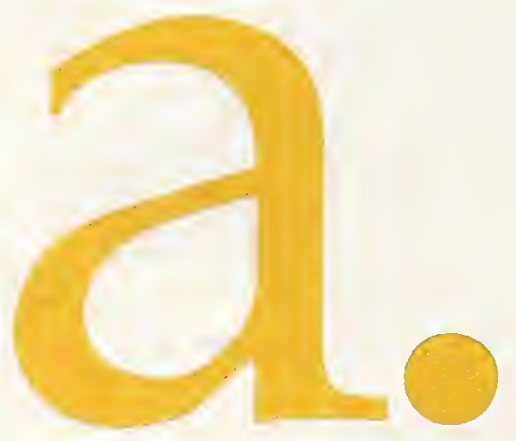

Alternate Solution

Room Dimensions in Feet

Length

$15 \frac{7}{12}$ feet

Width

$12 \frac{1}{2}$ feet

$15 \frac{7}{12} \times 12 \frac{1}{2}$ square feet

$\frac{187}{12} \times \frac{25}{2}=$

$\frac{4675}{24}$ square feet

$=194 \frac{19}{24}$ square feet

= 22 square yards (approx.)

Problem: What is the area of the floor of a room with the following dimensions?

$\begin{array}{lll} & \text { Customary Units } & \text { Metric Units } \\ \text { Length } & 15 \mathrm{ft} 7 \text { in } & 475 \text { centimeters } \\ \text { Width } & 12 \mathrm{ft} 6 \text { in } & 380 \text { centimeters }\end{array}$

SOLUTION. The area is determined by multiplying the length of the room by its width. Note that for room dimensions given in mixed customary units it is necessary to first reduce them to a common unit expression which, in this case, may be either feet or inches.

\section{CUSTOMARY- \\ Room Dimensions in Inches}

Multiply feet by 12 to convert to inches

Length $(15 \times 12)+7=187$ in

Width $(12 \times 12)+6=150$ in

$187 \times 150$

$=28050$ square inches

Total square inches divided by number of square inches in a square foot (144) equals number of square feet

$$
28050 \div 144=195
$$

square feet (approx.)

Total square feet divided by number of square feet in a square yard (9) equals number of square yards

$195 \div 9=22$ square yards (approx.)

\section{METRIC - \\ Room Dimensions in Centimeters}

\author{
Length $475 \mathrm{~cm}$ \\ Width $380 \mathrm{~cm}$

$$
\begin{gathered}
475 \times 380 \\
=180500 \text { square } \mathrm{cm}
\end{gathered}
$$

Total square centimeters divided by number of square centimeters in a square meter (10 000) equals number of square meters; i.e. move decimal point 4 places to left

$180500 \div 10000=$ 18 square meters (approx.) 


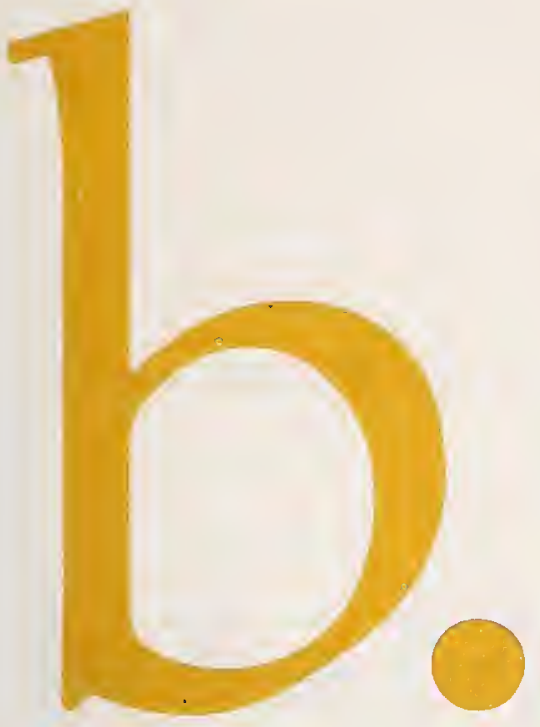

Alternate Solutions

\begin{tabular}{lrr|r} 
& $\mathrm{lb}$ & $\mathrm{oz}$ & $\mathrm{kg}$ \\
Meat & 4 & 9 & 2.07 \\
Potatoes & 3 & 4 & 1.47 \\
Tomatoes & 2 & 15 & 1.33 \\
Cereal & $\frac{1}{10}$ & $\frac{7}{35}$ & $\frac{0.65}{5.52}$ \\
& $\frac{12}{4}$ & 3 & \\
& Or 12 & \\
& Or $12 \mathrm{lb}$ & or & $5.5 \mathrm{~kg}$ \\
& (approx.) & \multicolumn{2}{c}{ (approx.) }
\end{tabular}

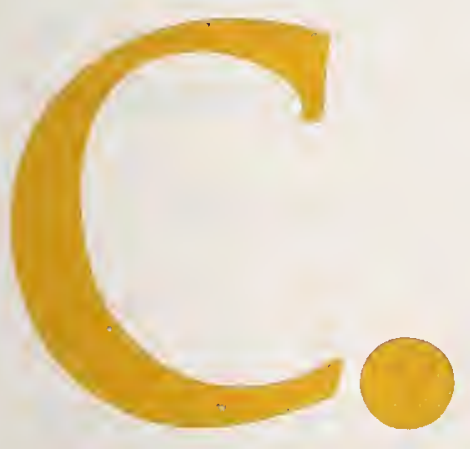

Alternate Solutions

\begin{tabular}{lccc|c} 
Milk & gal & $q t$ & $p t$ & liters \\
Water & 1 & 2 & 1 & 6.5 \\
Flavoring & & 3 & 1 & 3.5 \\
\multicolumn{1}{c}{ Totals } & 1 & $\overline{5}$ & $\frac{1 / 2}{21 / 2}$ & $\frac{0.25}{10.25}$ \\
& 2 & 2 & $1 / 2$ & \\
& or 21/2 gal & or 10 liters \\
& (approx.) & (approx.)
\end{tabular}

What is the approximate total weight of the contents of a basket that contains the following items:

\section{Weight}

Customary Units

$4 \mathrm{lb} 9 \mathrm{oz}$

$3 \mathrm{lb} 4 \mathrm{oz}$

$2 \mathrm{lb} 15 \mathrm{oz}$

$1 \mathrm{lb} 7 \mathrm{oz}$
Metric Units

2.07 kilograms

1.47 kilograms

1.33 kilograms 650 grams

\section{Solution of Problem}

Customary

Weight in Ounces

Weight in pounds multiplied

by 16 gives weight in ounces

\begin{tabular}{|c|c|c|}
\hline Meat & $(4 \times 16)+$ & 2070 by 1000 to \\
\hline Potatoes & $(3 \times 16)+4=52$ & 1470 convert \\
\hline Tomatoes & $(2 \times 16)+15=47$ & to grams \\
\hline Cereal & $(1 \times 16)+7=\frac{23}{105}$ & $\frac{650}{5520}$ \\
\hline
\end{tabular}

195 divided by $16=12$ lb (approx.) or 5.5 kilograms (approx.)

Metric

Weight in Grams

\section{multiply}

kilograms

\section{Volume}

What is the volume of the following two comparable but not equal mixtures:

$\begin{array}{lll} & \text { Customary } & \text { Metric } \\ \text { Units } & \text { Units } \\ \text { Milk } & 1 \text { gal } 2 \mathrm{qt} 1 \mathrm{pt} & 6.5 \text { liters } \\ \text { Water } & 3 \mathrm{qt} 1 \mathrm{pt} & 3.5 \text { liters } \\ \text { Flavoring } & 1 / 2 \mathrm{pt} & 250 \text { milliliters }\end{array}$

Solution of Problem

Customary

Volume in Pints

Multiply gallons by 8 , and quarts by 2 to convert to pints

Milk

$(1 \times 8)+(2 \times 2)+1=13$

Water

$(3 \times 2)+1=7$

Flavoring
Metric Volume in Milliliters

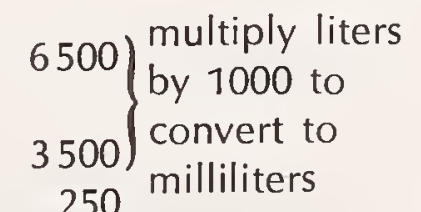

\section{to}




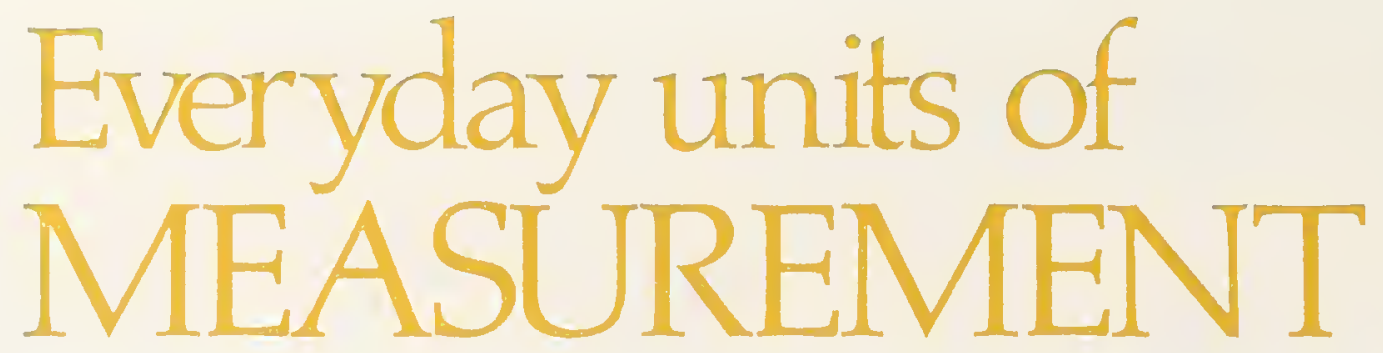

The few metric units of measurement that we will be using in our everyday lives and their approximate sizes are given on this page.

\begin{tabular}{lll} 
Measurement & $\begin{array}{l}\text { Metric } \\
\text { Unit }\end{array}$ & $\begin{array}{l}\text { Approximate } \\
\text { Size of Unit }\end{array}$ \\
\hline millimeter & diameter of a paper clip wire \\
meter & $\begin{array}{l}\text { a little more than the width } \\
\text { of a paper clip (about } 0.4 \text { inch) }\end{array}$ \\
kilometer & $\begin{array}{l}\text { a little longer than a yard } \\
\text { (about } 1.1 \text { yards) }\end{array}$ \\
& $\begin{array}{l}\text { somewhat further than } 1 / 2 \text { mile } \\
\text { (about } 0.6 \text { mile) }\end{array}$
\end{tabular}

Weight (mass) gram

a little more than the weight of a paper clip

kilogram

a little more than 2 pounds (about 2.2 pounds)

metric ton

a little more than a short ton (about 2200 pounds)

Volume

milliliter

five of them make a teaspoon

liter

a little larger than a quart (about 1.06 quarts)

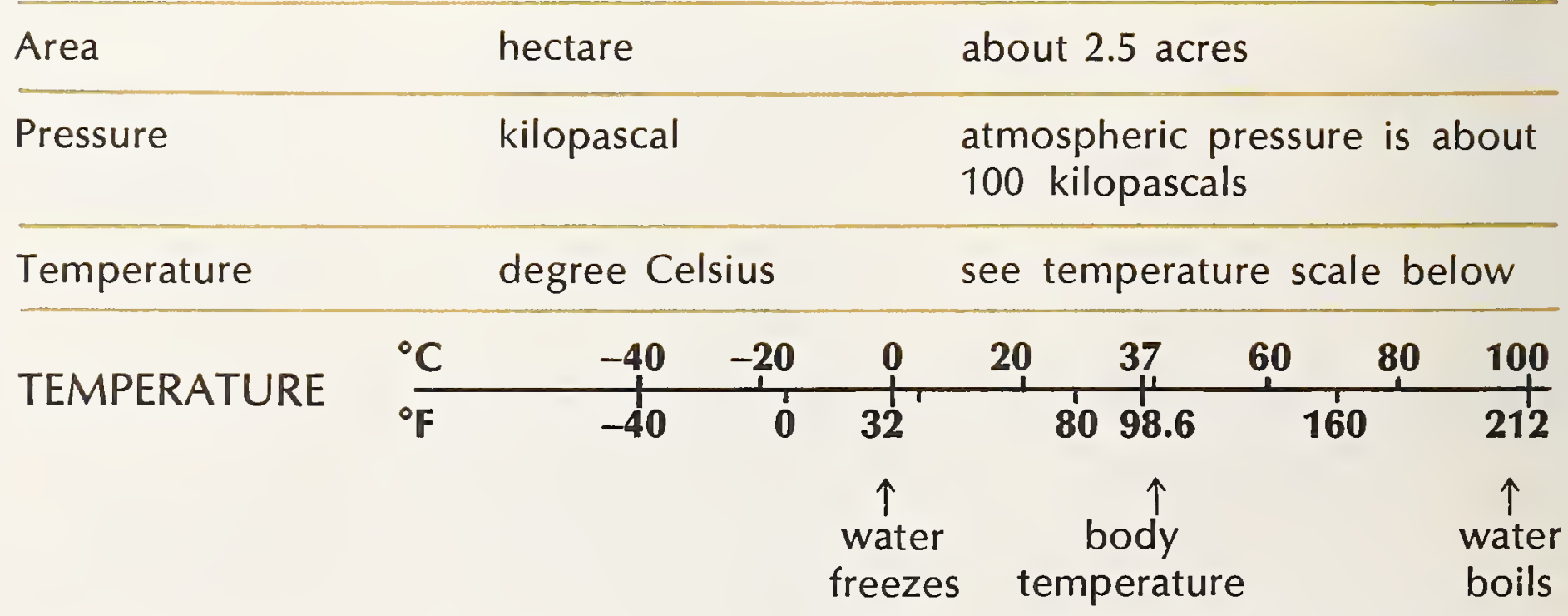




\section{in the MARKETPLACE}

A s metric measures become commonplace, one of the first things you will notice as you shop will be the new metric expressions for weight, volume, and length on packaged goods.

Currently, in packaged foods, the number of different expressions of measurement you encounter in one day's shopping is bewildering. Weights are expressed in avoirdupois ounces and pounds; fluid measures are expressed in gallons, liquid quarts, pints, and fluid ounces; and dry measures are expressed in bushels, pecks, dry quarts, and pints. Only our long familiarity with the customary system has made it usable.

With metric labeling, weight will be expressed only in grams or kilograms; volume will be expressed only in liters or milliliters; and length will be expressed only in meters, centimeters or millimeters. Clearly, metric is much less confusing and will be much easier to use when shopping.

\section{in the HOME}

Some of the most frequent measurements made in the home are those for cooking and baking. The practice that will be most generally followed in metric recipes should not differ from our current practice. Metric "cup and spoon" measures are only slightly larger than, and can 
be used interchangeably with, the customary "cup and spoon" measures in common use in American households. It is only those few ingredients that are now measured by weight (pounds and ounces) that will be expressed differently in metric recipes. To convert a customary recipe to metric just remember that a pound is about 450 grams and an ounce is about 28 grams.

Temperatures in metric recipes are given in degrees Celsius rather than degrees Fahrenheit. If your range thermometer or thermostat is calibrated in degrees Fahrenheit, simply multiply the Celsius temperature given in your recipe by 2 to obtain, quite closely, the corresponding Fahrenheit temperature. This method of conversion is accurate within $9^{\circ} \mathrm{F}$ over the range $240-400^{\circ} \mathrm{F}$.

\section{asaWORKER}

any mechanics, machinists, and assembly plant workers will use metric tools, such as wrenches, dies, and taps, that are different in size from those now used. For a while, because of the need to maintain tools in metric and customary unit sizes, they will have a larger number of such tools from which to select. In the long run, however, use of metric units and tools should reduce the number of tools required as the number of sizes of fasteners and other components used in the manufacture of products is reduced.

Sales personnel in hardware, paint, and fabric stores will also be affected by the metric changeover. When a customer wishes to purchase lumber or paint or wallpaper, the hardware store employee may be required to calculate for the customer the amount needed to cover an area with paint or wallpaper, or how much lumber will be needed to build a deck. With the use of metric, these calculations will be less complicated. The fabric store employee may likewise be asked to calculate the amount of cloth needed to drape a window, cover a chair, or make a dress.

For most other workers, the knowledge of metric units that they will learn as consumers will enable them to carry out their duties as efficiently as in the past. 


\section{A Word from the Acting Director}

hope you have found this booklet helpful in

understanding the metric system of measurement, particularly as it pertains to your everyday life. With passage of the Metric Conversion Act of 1975, we have entered a new, accelerated phase on the road to metric-a phase that makes this booklet, newly revised, even more useful.

It is now national policy to coordinate and plan for increasing use of the metric system. More and more we will see the results of this policy as our children are taught the metric system in school; as road signs on our highways begin to give distances in kilometers and speed limits in kilometers per hour; as more consumer goods are made and labeled to metric specifications; and as the news media disseminate information in metric units.

The National Bureau of Standards has been proud to serve as the Nation's principal metric resource during the period of national policy debate. Although many of the Bureau's metric information functions will be assumed by the new U.S. Metric Board, NBS will continue to serve as the authoritative source of accurate, compatible, and useful physical measurements. We will also continue to work with State and Federal agencies, universities, industry, and other groups as the focal point for assuring the integrity of measurements used throughout the United States.

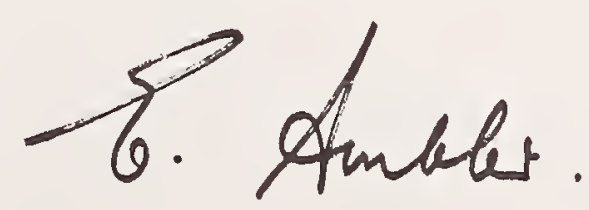

ERNEST AMBLER 


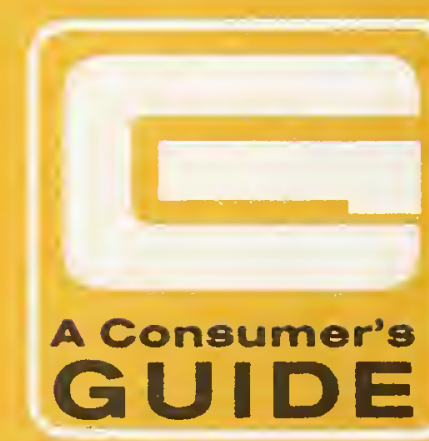

FROM THE NATIONAL BUREAU OF STANDARDS U.S. DEPARTMENT OF COMMERCE by

Louis E. Barbrow

Coordinator of Metric Activities Institute for Applied Technology National Bureau of Standards Washington, D.C. 20234

NBS CONSUMER INFORMATION SERIES 7 Editor: Suellen Halpin

Center for Consumer Product Technology Institute for Applied Technology National Bureau of Standards

Issued: October 1973

Revised: October 1976

U.S. DEPARTMENT OF COMMERCE

Elliot L. Richardson, Secretary

Edward O. Vetter, Under Secretary

Dr. Betsy Ancker-Johnson, Assistant Secretary for Science and Technology

NATIONAL BUREAU OF STANDARDS

Ernest Ambler, Acting Director

For sale by the Superintendent of

Documents, U.S. Government Printing Office

Washington, D.C. 20402

Price 35 cents 


\title{
Brief History of
}

\section{$\mathrm{ME}$ E A SU UR: REMENT} SYS STE| EMS

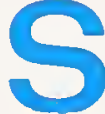

\section{with a Chart of the Modernized Metric System}

\begin{abstract}
"Weights and measures may be ranked among the necessaries of life to every individual of human society. They enter into the economical arrangements and daily concerns of every family. They are necessary to every occupation of human industry; to the distribution and security of every species of property; to every transaction of trade and commerce; to the labors of the husbandman; to the ingenuity of the artificer; to the studies of the philosopher; to the researches of the antiquarian, to the navigation of the mariner, and the marches of the soldier; to all the exchanges of peace, and all the operations of war. The knowledge of them, as in established use, is among the first elements of education, and is often learned by those who learn nothing else, not even to read and write. This knowledge is riveted in the memory by the habitual application of it to the employments of men throughout life."
\end{abstract}

\section{JOHN QUINCY ADAMS}

Report to the Congress, 1821

Weights and measures were among the earliest tools invented by man. Primitive societies needed rudimentary measures for many tasks: constructing dwellings of an appropriate size and shape, fashioning clothing, or bartering food or raw materials.

Man understandably turned first to parts of his body and his natural surroundings for measuring instruments. Early Babylonian and Egyptian records and the Bible indicate that length was first measured with the forearm, hand, or finger and that time was measured by the periods of the sun, moon, and other heavenly bodies. When it was necessary to compare the capacities of containers such as gourds or clay or metal vessels, they were filled with plant seeds which were then counted to measure the volumes. When means for weighing were invented, seeds and stones served as standards. For instance, the "carat," still used as a unit for gems, was derived from the carob seed.

As societies evolved, weights and measures became more complex. The invention of numbering systems and the science of mathematics made it possible to create whole systems of weights and measures suited to trade and commerce, land division, taxation, or scientific research. For these more sophisticated uses it was necessary not only to weigh and measure more complex things-it was also necessary to do it accurately time after time and in different places. However, with limited international exchange of goods and communication of ideas, it is not surprising that different systems for the same purpose developed and became established in different parts of the world-even in different parts of a single continent.

\section{The English System}

The measurement system commonly used in the United States today is nearly the same as that brought by the colonists from England. These measures had their origins in a variety of culturesBabylonian, Egyptian, Roman, AngloSaxon, and Norman French. The ancient "digit," "palm," "span," and "cubit" units evolved into the "inch," "foot," and "yard" through a complicated transformation not yet fully understood.

Roman contributions include the use of the number 12 as a base (our foot is divided into 12 inches) and words from which we derive many of our present weights and measures names. For example, the 12 divisions of the Roman "pes," or foot, were called unciae. Our words "inch" and "ounce" are both derived from that Latin word.

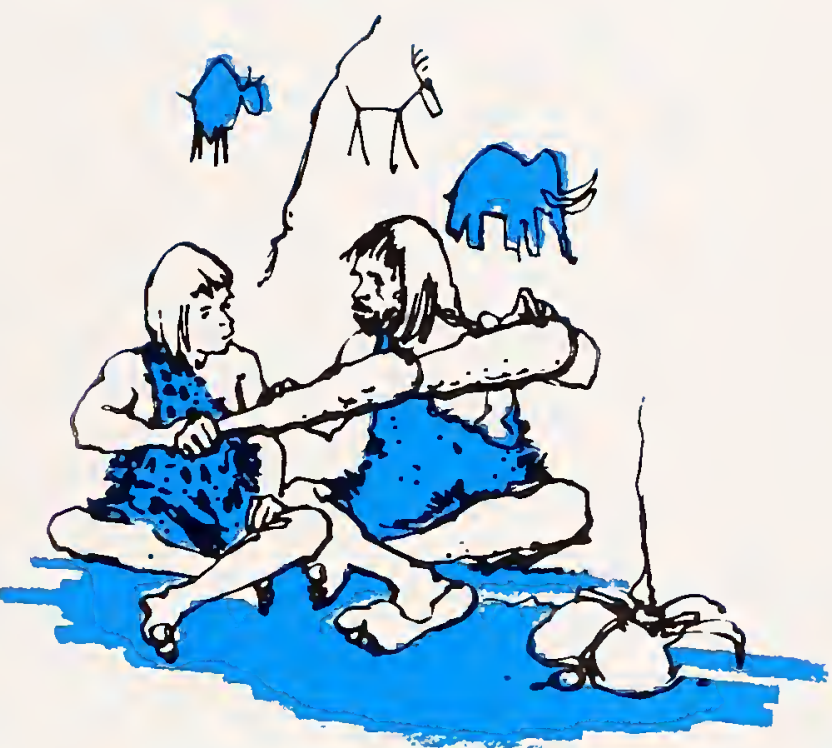

The "yard" as a measure of length can be traced back to the early Saxon kings. They wore a sash or girdle around the waist-that could be removed and used as a convenient measuring device. Thus the word "yard" comes from the Saxon word "gird" meaning the circumference of a person's waist.

Standardization of the various units and their combinations into a loosely related system of weights and measures sometimes occurred in fascinating ways. Tradition holds that King Henry I decreed that the yard should be the distance from the tip of his nose to the end of his thumb. The length of a furlong (or furrow-long) was established by early Tudor rulers as 220 yards. This led Queen Elizabeth I to declare, in the 16 th century, that henceforth the traditional Roman mile of 5000 feet would be replaced by one of 5280 feet, making the mile exactly 8 furlongs and providing a convenient relationship between two previously ill-related measures.

Thus, through royal edicts, England by the 18 th century had achieved a greater degree of standardization than the continental countries. The English units were well suited to commerce and trade because they had been developed and refined to meet commercial needs. Through colonization and dominance of world commerce during the 17 th, 18 th, 


\section{THE MODERNIZED}

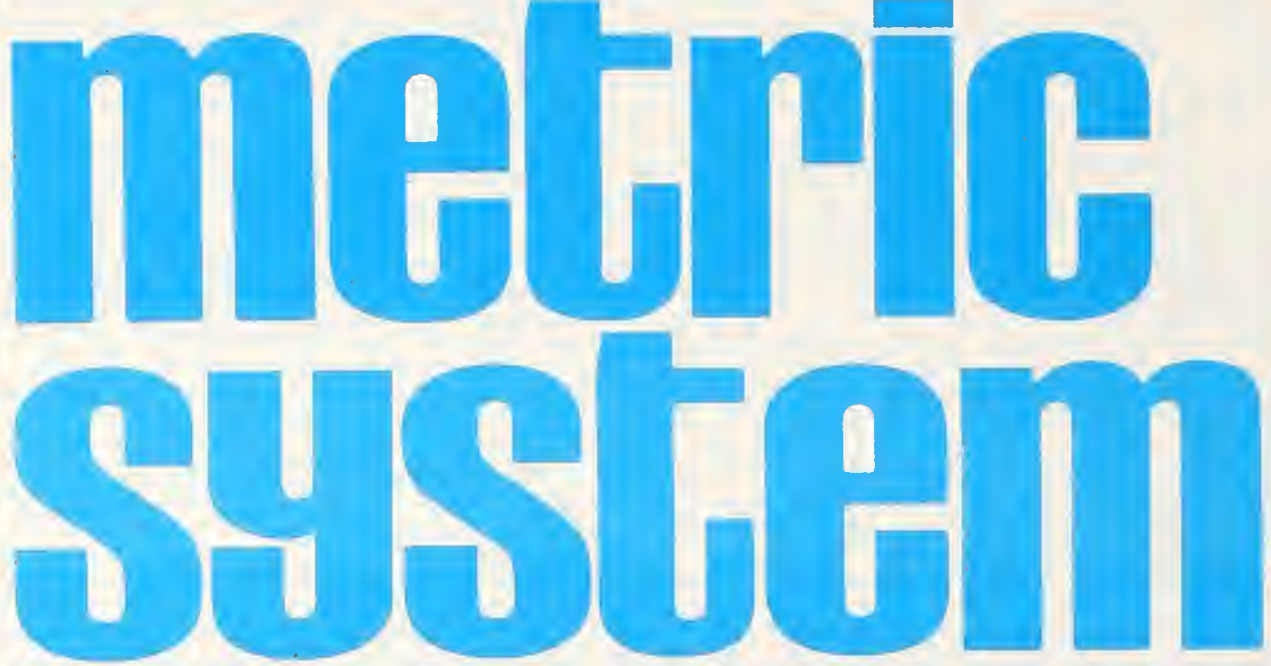

\section{The International System of Units-SI} is a modernized version of the metric system established by international agreement. It provides a logical and interconnected framework for all measurements in science, industry, and commerce. Officially abbreviated $\mathrm{SI}$, the system is built upon a foundation of seven base units, plus two supplementary units, which appear on this chart along with their definitions. All other SI units are derived from these units. Multiples and submultiples are expressed in a decimal system. Use of metric weights and measures was legalized in the United States in 1866, and since 1893 the yard and pound have been defined in terms of the meter and the kilogram. The base units for time, electric current, amount of substance, and luminous intensity are the same in both the customary and metric systems.

\begin{tabular}{|c|c|c|c|c|}
\hline Symbot & $\begin{array}{l}\text { When You Know } \\
\text { Number of }\end{array}$ & Multipty by & $\begin{array}{l}\text { To Find } \\
\text { Number of }\end{array}$ & Symbo \\
\hline in & inches & ^25.4 & ${ }^{B}$ millimeters & $\mathrm{mm}$ \\
\hline it & feet & ${ }^{\wedge} 0.3048$ & meters & $\mathrm{m}$ \\
\hline yd & yards & ${ }^{A} 0.9144$ & meters & \\
\hline & miles & 1.60934 & kilometers & $\mathrm{km}$ \\
\hline \multirow[t]{2}{*}{$y d^{2}$} & square yards & 0.836127 & square meters & $\mathrm{m}^{2}$ \\
\hline & & 0.404686 & chectares & \\
\hline$y d^{3}$ & cubic yards & 0.764555 & cubic meters & $m^{3}$ \\
\hline qt & quarts (lq) & 0.946353 & 'liters & L \\
\hline oz & ounces (avdp) & 28.3495 & grams & \\
\hline & pounds (avdp) & 0.453592 & kilograms & $\mathrm{kg}$ \\
\hline${ }^{\circ} \mathrm{F}$ & $\begin{array}{l}\text { degrees } \\
\quad \text { Fahrenheit }\end{array}$ & $\begin{array}{l}\text { "5/9 (after sub- } \\
\text { tracting 32) }\end{array}$ & $\begin{array}{l}\text { degrees } \\
\text { Celsius }\end{array}$ & ${ }^{\circ} \mathrm{C}$ \\
\hline $\mathrm{mm}$ & millimeters & 0.0393701 & inches & in \\
\hline $\mathrm{m}$ & meters & 3.28084 & feet & it \\
\hline $\mathrm{m}$ & meters & 1.09361 & yards & yd \\
\hline $\mathrm{km}$ & kilometers & 0.621371 & miles & $\mathrm{mi}$ \\
\hline$m^{2}$ & square meters & 1.19599 & square yards & $y d^{2}$ \\
\hline ha & ${ }^{c}$ nectares & 2.47105 & acres & \\
\hline$m^{3}$ & cubic meters & 1.30795 & cubic yards & $y d^{3}$ \\
\hline L & ${ }^{\circ}$ liters & 1.05669 & quarts (Iq) & qt \\
\hline 9 & grams & 0.0352740 & ounces (avdp) & oz \\
\hline kg & kilograms & 2.20462 & pounds (avdp) & Ib \\
\hline \multirow[t]{2}{*}{${ }^{\circ} \mathrm{C}$} & degrees & A9/5 (then & degrees & ${ }^{\circ} \mathrm{F}$ \\
\hline & Celsius & add 32) & Fahrenheit & \\
\hline
\end{tabular}

for example, 1 in $=25.4 \mathrm{~mm}$, so 3 inches would be in) $\left(25.4 \frac{\mathrm{mm}}{\mathrm{in}}\right)=76.2 \mathrm{~mm}$

hectare is a common name for 10000 square meters

liter is a common name for fluid volume of 0.001 cubic meter Most symbols are written with lower case letters; exceptions are units named after persons for which the symbols are capitalized. Periods are not used with any symbols.

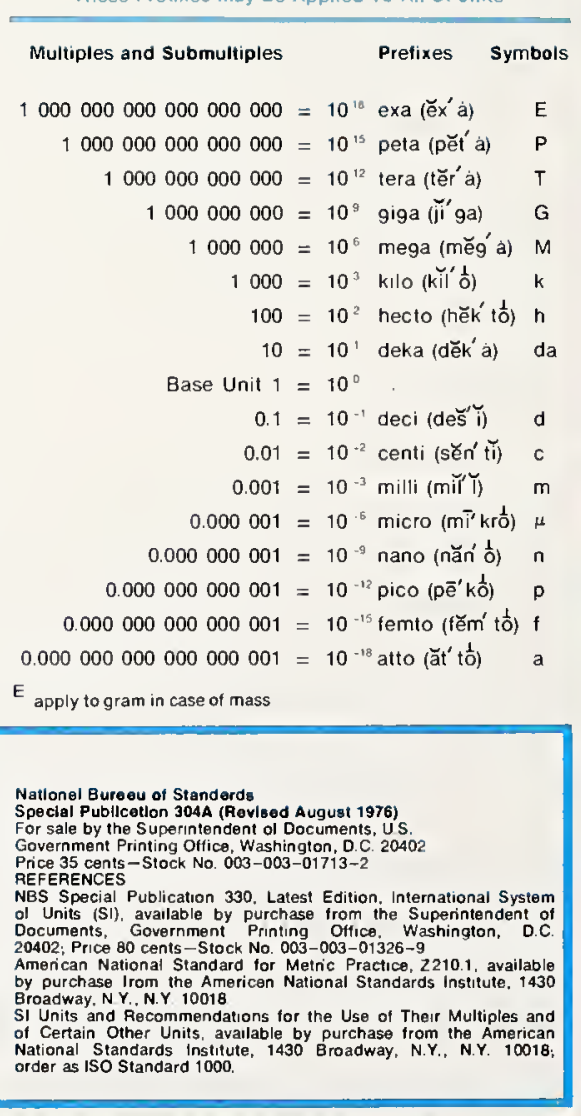

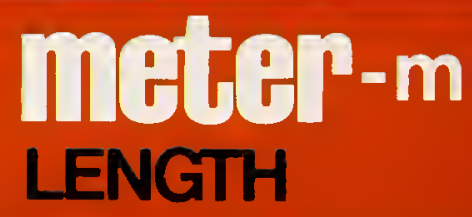
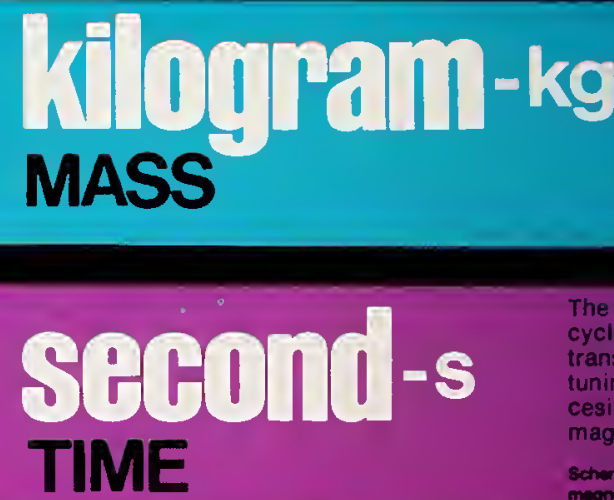

\section{athere-A \\ ELECTRIC CURRENT}

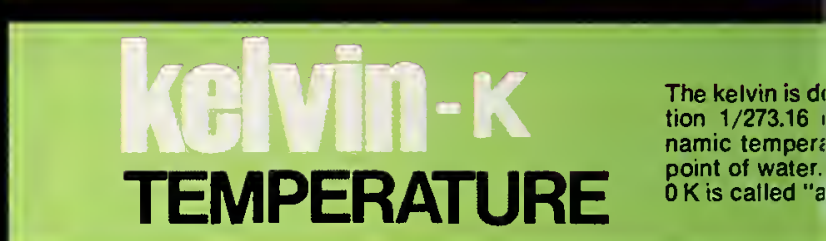

\section{(II) $\mathrm{P}$-mol \\ AMOUNT OF SUBSTAN}

\section{Pillifiti-cd \\ LUMINOUS INTENSTTY}

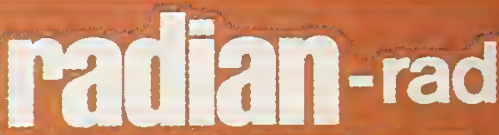

PLANE ANGLE
The radian is súbtended by the radius. 


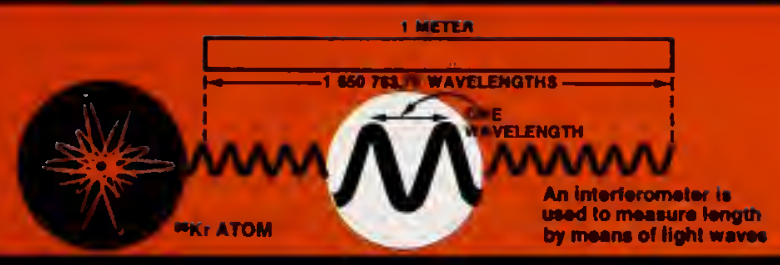

for the unit of mass, the kilogram, is a Siatinum-iridium alloy kept by the Internaof Weights and Measures at Paris. A dua custody of the National Bureau of Stand-
as the mass standard for the United States. nly base unit still defined by an artifact. ormmonly used term for "mass"

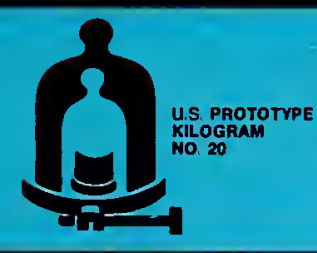

The SI unit of force is the newton (N). One neuton is the force which, when applied to a 1-kilogram mass, will give the kilogram mass an acceleratio
1 (meter per second) per second. $1 \mathrm{~N}=1 \mathrm{kgm} / \mathrm{s}^{2}$
The SI unit of area is the square motor $\left(\mathrm{m}^{\prime}\right)$

The SI unit of volume is the cuble moter $\left(\mathrm{m}^{3}\right)$. The iter ( 0.001 cubic meter), although not an SI unit, is commonly used to measure fluid volume.

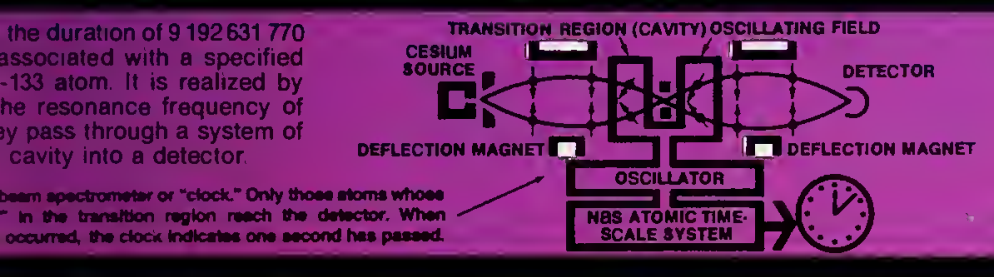

The number of periods or cycles per second is called frequency. The SI unit for frequency is the hertz $(\mathrm{Hz})$. One hertz equals one cycle per second.

The SI unit for speed is the meler per second $(\mathrm{m} / \mathrm{s})$.

The SI unit for acceleration is the (meler per second) per second $\left(\mathrm{m} / \mathrm{s}^{2}\right)$
The SI unit for pressure is the pascal $(\mathrm{Pa})$ $1 \mathrm{~Pa}=1 \mathrm{~N} / \mathrm{m}^{2}$

The SI unit for work and energy of any kind is the joule $(\mathrm{J})$

$1 \mathrm{~J}=1 \mathrm{~N} \cdot \mathrm{m}$

The SI unit for power of any kind is the watt $(W)$

$1 \mathrm{~W}=1 \mathrm{~J} / \mathrm{s}$ pere is defined as that current which, if maintained in each of two Irallel wires separated by one meter in free space, would produce between the two wires (due to their magnetic fields) of $2 \times 10^{-7}$ for each meter of length.

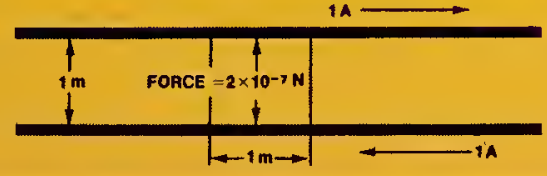

The SI unit of voltage is the volt (V).

The SI unit of electric resistance is the ohm $(\Omega)$ $1 \Omega=1 \mathrm{~V} / \mathrm{A}$

he frac-
armody-
ie triple
eerature
Ero".

1.8 Fahrenhelt degrees are equal to $1.0^{\circ} \mathrm{C}$ or $1.0 \mathrm{~K}$ responding to $0^{\circ} \mathrm{C}$.
Standard frequencies and correct time are broadcast from WWV, WWVB, and WWVH, and stations of the U.S. Navy. Many shortfrequencies of $2.5,5,10,15$, and 20 megahertz.

The mole is the amount of substance of a system that contains as many elementary entities as there a
kilogram of carbon 12

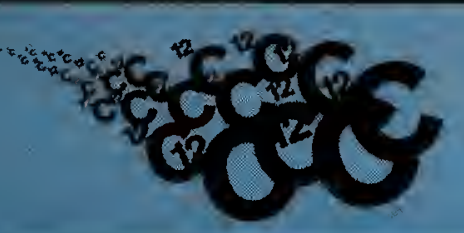

When the mole is used, the elementary entities must be specified and may be atoms, molecules, ions, electrons, other particles, or specified groups of such particles.
The \$I unit of concentration lof amount of substance) is the mole per eubic meter $\left(\mathrm{mol} / \mathrm{m}^{3}\right)$.
The candela is delined as the luminous intensity of $1 / 600000$ of a square meter of a blackbody at the temperature of hecting platinum (2045 16$)$.

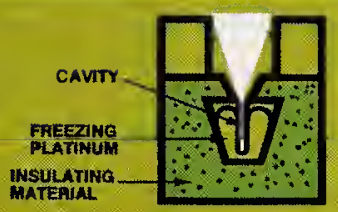

The SI unit of light flux is the lumen (Im). A source having an Intensity of 1 candela in all directlons radiates a light ilux of $4 \pi$ lumens.
The standard temperature at the triple point of water is provided by a special cell, an evacuated glass cylinder containpure water. When the cell is cooled until a mantle of ice forms around the reentrant well, the temperature at the interace of solid, liquid, and vapor is $27316 \mathrm{~K}$ Thermometers to be calibrated are placed in the reentrant well.

\section{TWO SUPPLEMENTARY UNITS}
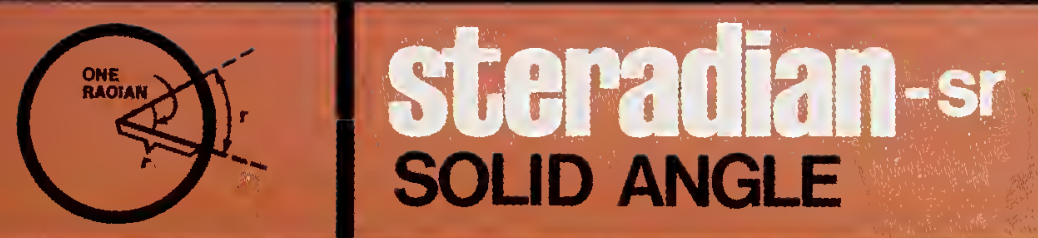

The steradian is the solid angle with its vertex at the center of a sphere that is subtended by an area of the spherical surface equal to that of a square with
the radius.

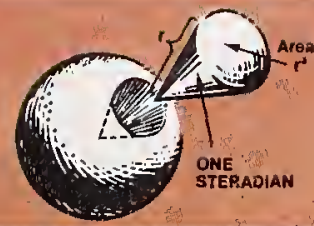


and 19th centuries, the English system of weights and measures was spread to and established in many parts of the world, including the American colonies.

However, standards still differed to an extent undesirable for commerce among the 13 colonies. The need for greater uniformity led to clauses in the Articles of Confederation (ratified by the original colonies in 1781) and the Constitution of the United States (ratified in 1790) giving power to the Congress to fix uniform standards for weights and measures. Today, standards supplied to all the States by the National Bureau of Standards assure uniformity throughout the country.

\section{The Metric System}

The need for a single worldwide coordinated measurement system was recognized over 300 years ago. Gabriel Mouton, Vicar of St. Paul in Lyons, proposed in 1670 a comprehensive decimal measurement system based on the length of one minute of arc of a great circle of the earth. In 1671 Jean Picard, a French astronomer, proposed the length of a pendulum beating seconds as the unit of length. (Such a pendulum would have been fairly easily reproducible, thus facilitating the widespread distribution of uniform standards.) Other proposals were made, but over a century elapsed before any action was taken.

In 1790, in the midst of the French Revolution, the National Assembly of France requested the French Academy standard for all the measures and all the weights." The Commission appointed by the Academy created a system that was, at once, simple and scientific. The unit of length was to be a portion of the earth's circumference. Measures for caof Sciences to "deduce an invariable

pacity (volume) and mass (weight) were to be derived from the unit of length, thus relating the basic units of the system to each other and to nature. Furthermore, the larger and smaller versions of each unit were to be created by multiplying or dividing the basic units by 10 and itsıpowers. This feature provided a great convenience to users of the system, by eliminating the need for such calculations as dividing by 16 (to convert ounces to pounds) or by 12 (to convert inches to feet). Similar calculations in the metric system could be performed simply by shifting the decimal point. Thus the metric system is a "base-10" or "decimal" system.

The Commission assigned the name metre - which we spell meter - to the unit of length. This name was derived from the Greek word metron, meaning "a measure." The physical standard representing the meter was to be constructed so that it would equal one ten-millionth of the distance from the north pole to the equator along the meridian of the earth running near Dunkirk in France and Barcelona in Spain.

The metric unit of mass, called the "gram," was defined as the mass of one cubic centimeter (a cube that is $1 / 100$ of a meter on each side) of water at its temperature of maximum density. The cubic decimeter (a cube $1 / 10$ of a meter on each side) was chosen as the unit of fluid capacity. This measure was given the name "liter."

Although the metric system was not accepted with enthusiasm at first, adoption by other nations occurred steadily after France made its use compulsory in 1840. The standardized character and decimal features of the metric system made it well suited to scientific and engineering work. Consequently, it is not surprising that the rapid spread of the

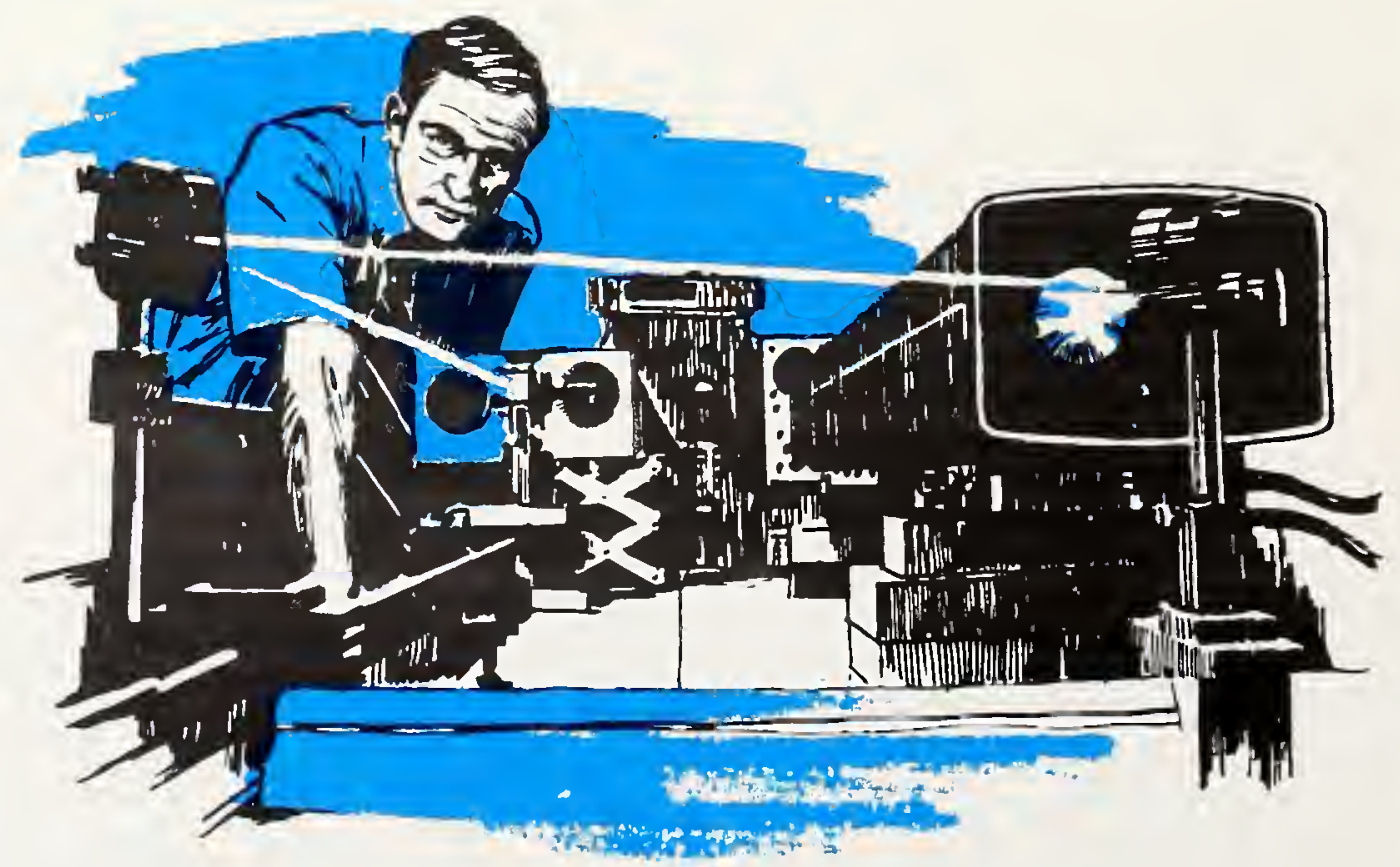

system coincided with an age of rapid technological development. In the United States, by Act of Congress in 1866 , it was made "lawful throughout the United States of America to employ the weights and measures of the metric system in all contracts, dealings or court proceedings."

By the late 1860's, even better metric standards were needed to keep pace with scientific advances. In 1875 , an international treaty, the "Treaty of the Meter," set up well-defined metric standards for length and mass, and established permanent machinery to recommend and adopt further refinements in the metric system. This treaty, known as the Metric Convention, was signed by 17 countries, including the United States.

As a result of the Treaty, metric standards were constructed and distributed to each nation that ratified the Convention. Since 1893, the internationally agreed-to metric standards have served as the fundamental weights and measures standards of the United States.

By 1900 a total of 35 nations-including the major nations of continental Europe and most of South Americahad officially accepted the metric system. Today, with the exception of the United States and a few small countries, the entire world is using predominantly the metric system or is committed to such use. In 1971 the Secretary of Commerce, in transmitting to Congress the results of a 3-year study authorized by the Metric Study Act of 1968, recommended that the U.S. change to predominant use of the metric system through a coordinated national program. The Congress is now considering this recommendation.

The International Bureau of Weights and Measures located at Sevres, France, serves as a permanent secretariat for the Meter Convention, coordinating the exchange of information about the use and refinement of the metric system. As measurement science develops more precise and easily reproducible ways of defining the measurement units, the General Conference on Weights and Measures-the diplomatic organization made up of adherents to the Conventionmeets periodically to ratify improvements in the system and the standards.

In 1960, the General Conference adopted an extensive revision and simplification of the system. The name $L e$ Système International d'Unités (International System of Units), with the international abbreviation SI, was adopted for this modernized metric system. Further improvements in and additions to SI were made by the General Conference in $1964,1968,1971$, and 1975 . 

